Helgoländer wiss. Meeresunters. 31, 55-101 (1978)

\title{
Experiments on epibenthic predation in the Wadden Sea
}

\author{
K. REISE \\ Biologische Anstalt Helgoland (Litoralstation); \\ D-2282 List/Sylt, Federal Republic of Germany
}

\begin{abstract}
Field experiments were designed to evaluate the role of predators in the Wadden Sea, small predators like shore crabs, shrimps and gobies, and large ones like flatish and birds. Exclosures, maintained in a Corophium volutator bed, an eelgrass bed, in a sandy and a muddy flat, protected the infauna from such epibenthic predation. The resulting changes in the macrofauna were recorded and compared with an unaffected control area. In sandy and muddy flats of the lower intertidal zone, cages (mesh size $\leq 5 \mathrm{~mm}$ ) altered abundance and composition of the infauna almost entirely. Nearly all species achieved higher population densities than in the control area, and in addition, the number of species increased as well. In the the scarcely populated mud flat a dense suspension-feeder assemblage emerged, associated with numerous tube-building polychaetes. The sand flat, normally dominated by deposit feeders, also became occupied by a dense suspension-feeder assemblage, mainly cockles. In contrast, narrowly meshed cages had only little effect in the beds of eelgrass and of Corophium volutator. Both are positioned in the upper intertidal zone. Although a number of species still responded with significant increases in abundance, many remained indifferent or even tended to be less abundant within cages. Cages provided with a $20-\mathrm{mm}$ mesh nylon net, excluding only birds, flatfish and the biggest crabs, increased significantly the survival of large-sized infaunal members. This was only apparent in the upper intertidal zone. It was concluded, that small sized epibenthic predators are the major determinants of the dynamic species abundance pattern of the lower intertidal flats. In the eelgrass bed, the meshwork of rootlets constitutes an important spatial refuge from these predators. The complex habitat structure causes a diversified faunal assemblage. The Corophium bed in the uppermost intertidal zone is less accessable to predators like crabs, shrimp and gobies. The monotonous appearance of this faunal assemblage is assumed to be the outcome of competitive exclusion and of occasional harsh physical conditions.
\end{abstract}

\section{INTRODUCTION}

The most complex problem in ecology is to explain the natural pattern of species abundance. Although it is generally recognized that a whole set of physical and biological factors has to be considered, ecologists frequently evade complexity by proposing that simple components like salinity, grain size distribution, sewage, shading of canopy trees, etc., may serve as sufficient explanation for the observed patterns. Correlation studies, laboratory experiences, or intuition are the common sources of these statements. They have proved to be fairly resistant to falsification, 
Those observations that did not fit the statement are thought to be biased by an unusual factor not yet measured, rather than accepted as counter-evidence.

Obviously, this is not a very progressive line of research. The most promising approach to enhance understanding of the species abundance pattern is experimental manipulation in the field. One component is kept under control, while the others remain subject to the natural course of events.

In the rocky intertidal zone this method has proved to be very fruitful in extending our knowledge of community structure and abundance pattern (for review see Connell, 1973). In marine soft-sediment habitats only a few experimental

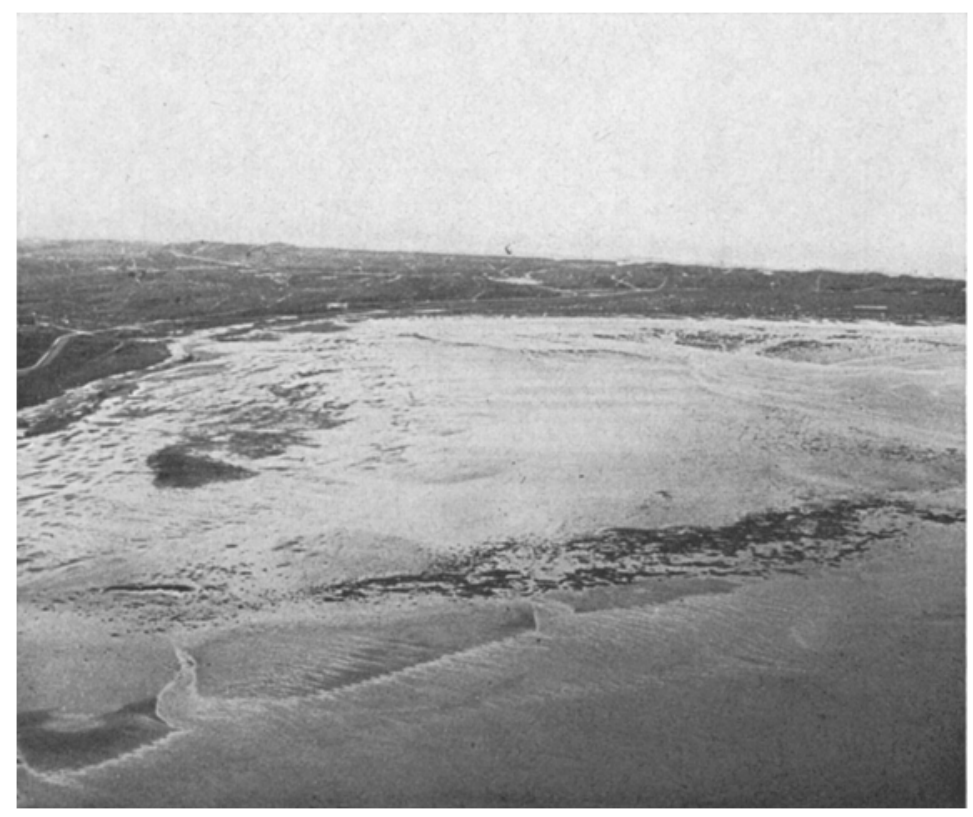

Fig. 1: Aerial photograph of study area during low tide in Königshafen, island of Sylt, showing the mussel banks close to low water mark (dark patches to the right) and the eelgrass belt (grey patches to the left) with an extensive sand flat in between. A sand-dune area is in the background. (With permission of the Luftamt Hamburg, Ifd. Nr. 1244/77)

studies have been done. Rhoads \& Young (1970) showed that deposit feeding bivalves caused physical instability in the sediment, thereby making it unsuitable for suspension feeders. Woodin (1974) detected competition for space among polychaetes in an intertidal mud flat. Woodin (1976b) also provided experimental evidence that polychaete tubes may constitute an important structural refuge from crab predation for co-occurring infaunal organisms.

The first predator exclusion experiment was conducted by Blegvad (1928). In the Limfjord he protected the macrobenthos from plaice predation with boxes of wire-gauze. A similar experiment in the western Baltic could not demonstrate fish predation, because starfish and crabs entered the cages (Arntz, 1977). Young et al. 
(1976) utilized predator exclusion cages in subtropical seagrass areas. At two sites the predatory impact of fishes could be recognized, while at a third site carnivorous decapod crustaceans intruded into the 12-mm meshed cages. In 1954 Smith had recognized crabs as important predators. He fenced out Carcinus maenas (L.) and observed an increasing abundance of the clam Mya arenaria L. Hancock \& Urquhart (1965) successfully used netting exclosures to protect cockles against oystercatchers.

In this paper, I report on predator exclusion experiments in the Wadden Sea near the island of Sylt (eastern part of the North Sea). Cages were maintained on intertidal flats to protect the infauna against bird predation during low tide, and against flatfish, gobies, shrimp and crabs during high tide. These field experiments are done in a sheltered bay called Königshafen (Fig. 1). The mean tidal range is $1.7 \mathrm{~m}$. Sediments vary from semi-fluid mud to coarse and clean sand in an intricate pattern (for detailed description see Wohlenberg, 1937). In the interior part of the bay I singled out four macrofaunal assemblages of which a brief and eclectic description is given. Among the epibenthic predators flatfish were rare during the period of investigation (1974-75), while Pomatoschistus (Gobius) microps (Kröyer), Crangon crangon (L.), and Carcinus maenas (L.) were highly abundant.

Infaunal changes within the exclosures elucidate the role these epibenthic predators play in the Wadden Sea. In addition, such experiments allow for a comparison on the relative importance of physical factors, competition, and predation as determinants of the dynamic pattern of infaunal abundances.

\section{MATERIAL AND METHODS}

\section{Field experiments}

Epibenthic predators were excluded from small plots by placing cages on the flats (Fig. 2). Predation by birds and large fish was prevented by digging in a tubular steel frame construction with a $20-\mathrm{mm}$ mesh nylon net attached to it. The height above the surface level was $45 \mathrm{~cm}$ and along the sides the nylon net penetrated $20 \mathrm{~cm}$ down into the sediment. This was achieved by anchoring heavy bricks to the net. Three cage sizes were used: $2.25,9$ and $25 \mathrm{~m}^{2}$. Cages to exclude predators of smaller size covered only $2500 \mathrm{~cm}^{2}$ each. They were provided with $5-\mathrm{mm}$ wire screen or with gauze of the mesh sizes 2,1 and $0.5 \mathrm{~mm}$, attached to iron rods. These exclosures were $15 \mathrm{~cm}$ high and the gauze penetrated $10 \mathrm{~cm}$ into the sediment. The clogging of the fine mesh was prevented by introducing 20 periwinkles Littorina littorea L. into each cage. These snails effectively grazed off all diatoms and other settling algae.

To quantify the infauna I took sediment samples with a steel corer, $100 \mathrm{~cm}^{2}$ by $20 \mathrm{~cm}$ deep. The sediment core was partitioned into three layers to which different extraction methods were applied: (a) depth 5-20 cm: washed through a 1-mm sieves in the field, the sieve contents were bottled and taken to the laboratory; (b) depth 2-5 cm: carefully washed through a $0.5-\mathrm{mm}$ sieve in a huge vat; (c) depth $0-2 \mathrm{~cm}$ : washed in a $1000 \mathrm{ml}$ glass beaker, and the supernatant was poured repeatedly through a $0.25-\mathrm{mm}$ sieve, and finally, the cleaned sand was searched for 
attached organisms. Each time the sieve contents were washed into white dishes from which all living animals were collected. The three different extraction methods took into account the prevailing size classes of the macrofauna at a certain depth. For identification and measurements the organisms were narcotized with $\mathrm{MgSO}_{4}$.

Sets of samples were taken to compare the caged and the control areas. Since the difference between plots usually exceeded by far within-plot variability, no more than eight samples were drawn from the small cages, four of which were processed as described above, and the others were merely washed through a $1-\mathrm{mm}$ sieve to obtain better estimates of the amount of larger specimens. From the $20-\mathrm{mm}$ cages and the control areas up to 16 samples were taken. In comparisons between caged and control areas, only the data of a single cage were sonsidered each time. Initially, the frequency distributions were tested with the F-statistic for equality of variances. But as the variances were almost always significantly different, the t-test was not applicable. I therefore tested for equal means using the Fisher-Behrens method. In case the frequency data did not fit a Poisson distribution I used the independent homogeneity test developed by Kolmogoroff and Smirnoff to decide whether they are drawn from different statistical populations. Differences were considered to be significant at the $5 \%$ level. The applied statistical methods are described in Sachs (1969).

To gain some information on the dispersion of the individuals at a scale of $100 \mathrm{~cm}^{2}$ sampling units, Lloyd's index of patchiness was calculated (Lloyd, 1967). The probability levels for random deviations of this index from expected randomness were determined by use of the critical values of the chi-square distribution.

\section{List of species}

The list comprises species referred to in the text; prominent ones are shortly characterized and taxonomic notes are given where indispensable.

Anthozoa

Sagartiogeton viduata (O. F. Mïller): attached to eelgrass leaves; determination not yet confirmed.

Gastropod a

Hydrobia nlvae (Pennant): deposit feeder and grazer, capable of pelagic migration, embryonic development in egg-capsules, spat most abundant in July; no other species of this genus occur in the area.

Littorina jugosa (Montagu) ( L. saxatilis ssp. jugosa): grazer, viviparious, release of juveniles between March and June.

Littorina littorea L.: deposit feeder and grazer, pelagic egg-capsules, spat most abundant from May to July. Littorina obtusata L., Retusa obtusa (Montagu).

Biva 1 via

Cerastoderma (Cardium) edule (L.): suspension feeder, spat abundant throughout 

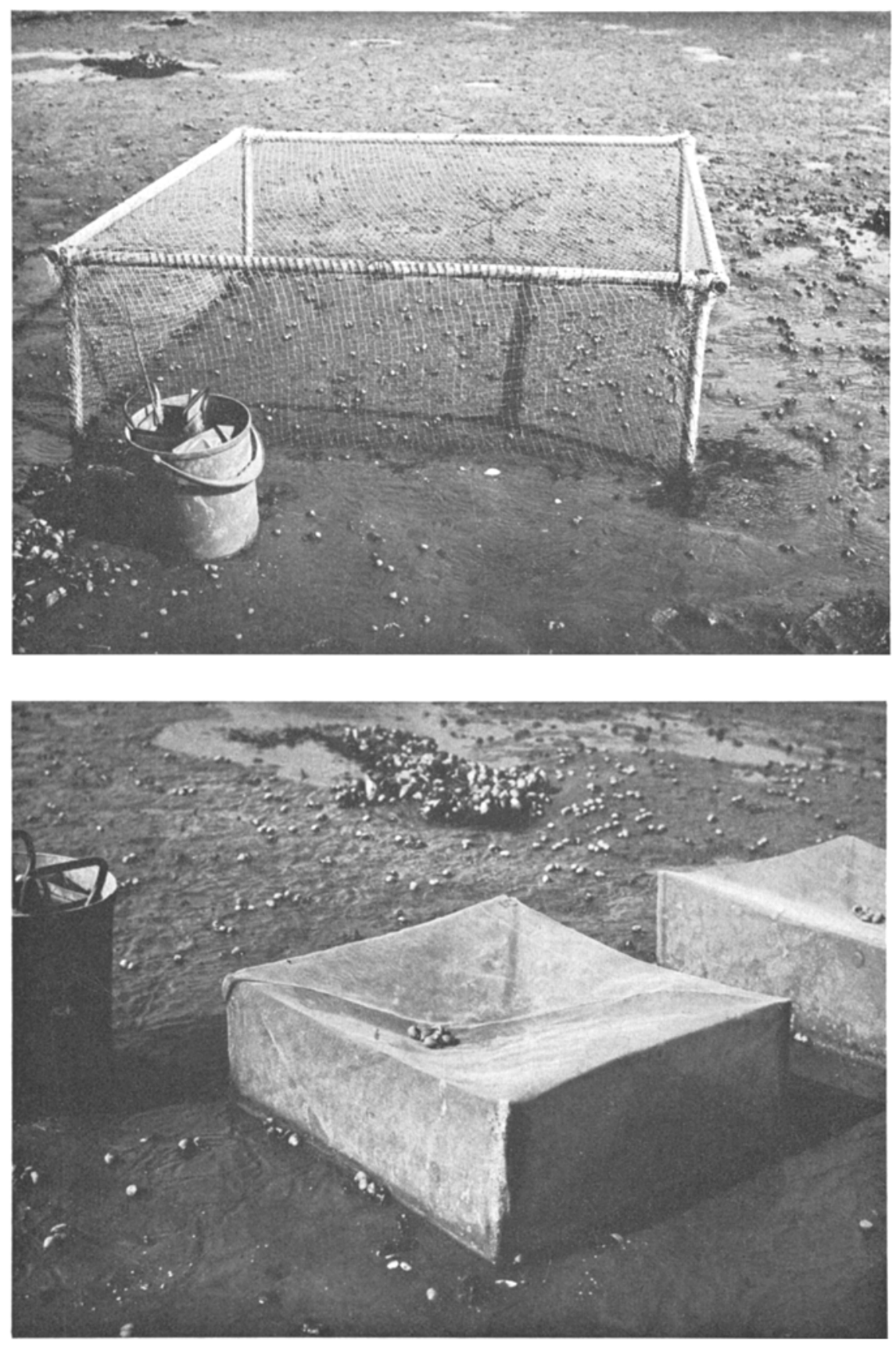

Fig. 2: Cages to exclude epibenthic predators in the mud flat area: netting exclosure with 20-mm mesh size (above) and cages out of $1-\mathrm{mm}$ mesh gauze (below) 
the year; the related C. glancum (Poiret) ( $=$ Cardium lamarcki Reeve) is rare in Königshafen.

Macoma baltica L.: deposit and suspension feeder, spatfall in May and June, secondary settlement does occur.

Angulus tenuis da Costa, Scrobicularia plana (da Costa), Abra alba (W. Wood), Venerupis pullastra Montagu, Spisula subtruncata da Costa, Mytilus edulis L.

Mya arenaria L.: suspension and deposit feeder (see Rasmussen, 1973), spatfall between June and August.

Nemertini

Amphiporus lactifloreus (Johnston), Tetrastemma melanocephalum (Johnston), Lineus viridis (Fabr.) Johnston (= L. ruber var. viridis).

Annelida

Harmothoe sarsi (Klingberg), Pholoe minuta (Fabr.), Eteone longa (Fabr.).

Anaitides mucosa (Oersted): predator and scavanger, eggs in gelatinous cocoons (March to June), pelagic larvae.

Microphthalmus spec.: two species in the experimental area, $M$. aberrans (Webster \&

Benedict) and $M$. sczelkowii Mecznikow, I did not separate them in the normal sorting procedure.

Nereis diversicolor O. F. Müller: scavanger, predator, deposit and suspension feeder, larval development semi-pelagic.

Nereis virens Sars.

Nephtys hombergi Savigny: predator, pelagic larvae.

Scoloplos armiger (O. F. Müller): burrowing deposit feeder, direct development in gelatinous cocoons (March to April).

Polydora (ligni) Webster: tube-building suspension and deposit feeder, predator, egg development in the maternal tube, pelagic larvae; individuals differ in several characters from the description of $P$. ligni as given in Hartmann-Schröder (1971), character transition to $P$. ciliata (Johnston) can be observed. This is in agreement with Rasmussen (1973) who considers both to be merely varieties of $P$. ciliata.

Pygospio elegans Claparede: tube-building deposit feeder, egg-development in the maternal tube, both, pelagic larvae and direct holobenthic development.

Spio filicornis (O. F. Müller), Malacoceros fuliginosus (Clap.).

Tharyx marioni (Saint-Joseph): tube-building deposit feeder, holobenthic development.

Capitella capitata (Fabr.): burrowing and tube-building deposit feeder, egg-development in the maternal tube, holobenthic development and pelagic larvae.

Heteromastus filiformis (Claparede): tube-building (with limited burrowing) deposit feeder, eggs in gelatinous cocoons (February), pelagic larvae.

Arenicola marina (L.): deposit feeder, lives in a tube and forms funnels and pilings of casts, holobenthic development, secondary settlement does occur.

Pectinaria koreni Malmgren, Ampharete acutifrons (Grube), Lanice conchilega (Pallas), Fabricia sabella Ehrenberg, Peloscolex benedeni (D'Udekem): deposit feeder; the only oligochaete species included in the study. 


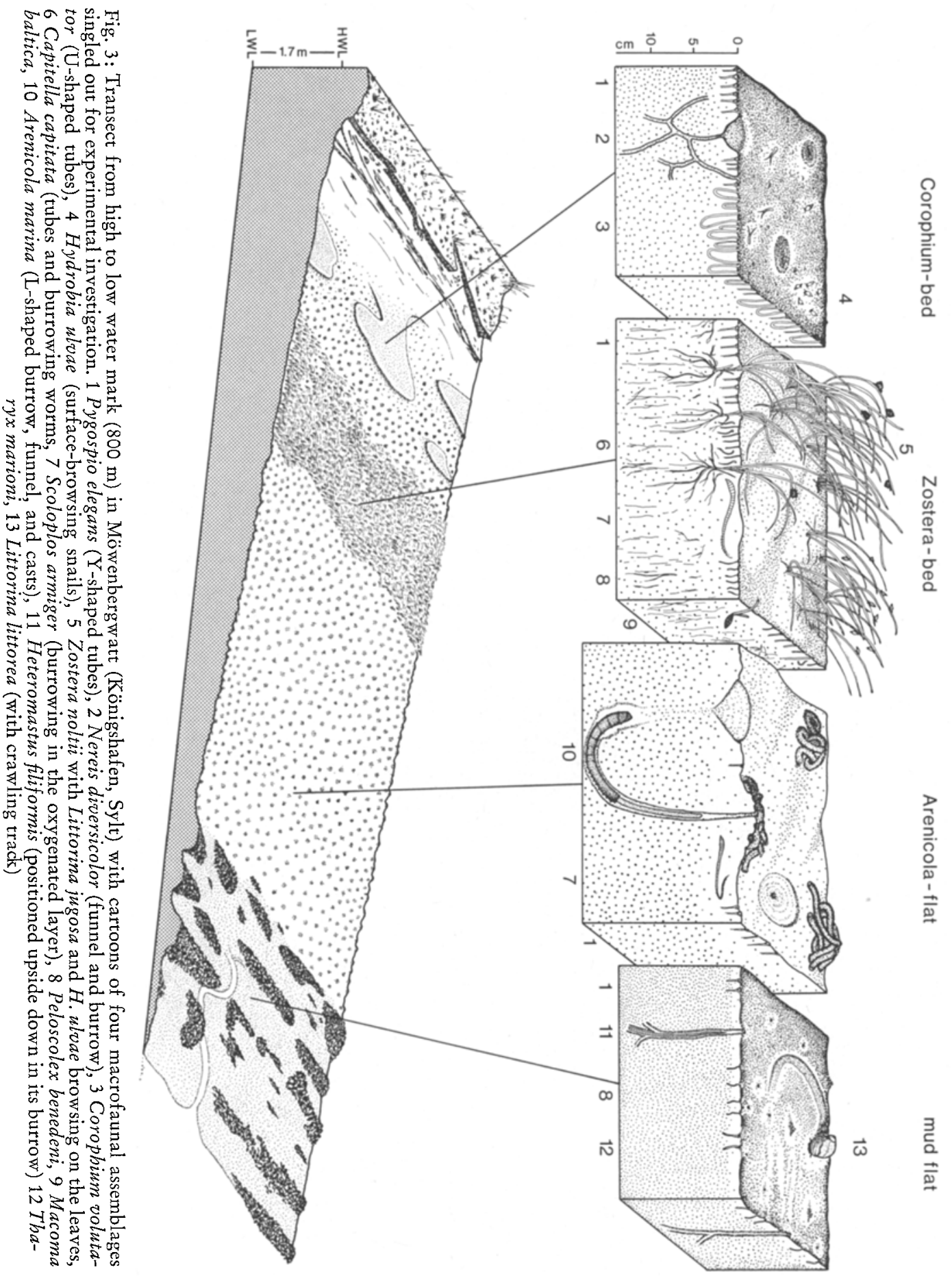


Crustacea

Gammarus locusta (L.): occasionally associated with Chaetogammarus (Gammarus) marinus (Leach).

Corophium volutator (Pallas): tube-building deposit and suspension feeder, brooding, juveniles may remain associated with the maternal tube.

Corophium arenarium Crawford.

Carcinus maenas (L.): predator, leaves the intertidal zone during winter, first wave of settling juveniles arrives in July.

Crangon crangon (L.): predator, high abundance of juveniles from July to October.

$\mathrm{P}$ is c e s

Pomatoschistus (Gobius) microps (Kröyer): predator, high abundance of juveniles from July to October.

\section{RESULTS}

Description of infaunal assemblages: physiognomy

Conventionally, the structure of communities is described by grouping individuals and species into distinguishable categories. This concept is somewhat problematic, since the degree of abstraction is dependent on the type of organism. Even the species does not always turn out to be a meaningful ecological category. Juvenile stages may

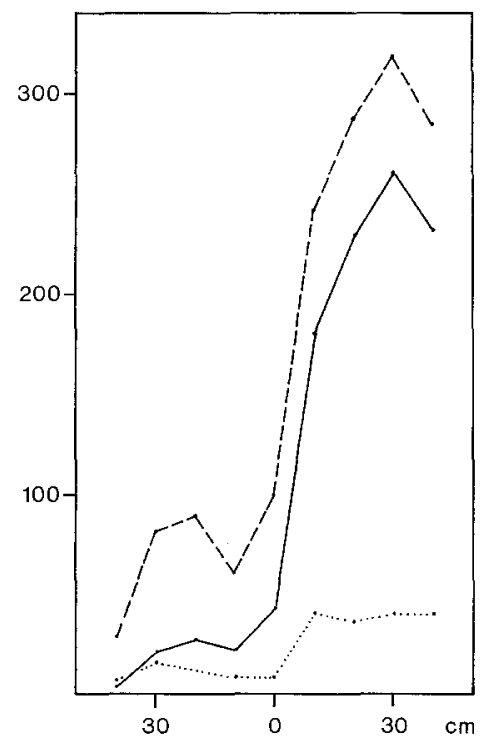

Fig. 4: Sharp boundary between Coropbium bed and Arenicold flat: abundances $100 \mathrm{~cm}^{-2}$ of Pygospio elegans (dotted line), Corophium spp. (straight line), and of the total (broken line) are given; the distance from the precipice (' 0 ') of the plateau is indicated along the abcissa 
occupy a niche quite different than the adults. To counterbalance some bias due to this abstraction, I placed in front of the numerical approach a general physiognomic description of the macrofaunal assemblages. Along a transect through the interior Könighafen (Möwenbergwatt) I singled out four assemblages for closer investigation (Fig. 3): (a) a Corophium volutator bed close to high water mark (b) a seagrass bed with the small eelgrass Zostera noltii Hornem. ( $Z$. nana Roth) dominating (c) a sand flat characterized by Arenicola marina and (d) a mud flat sheltered by mussel banks close to low water mark.

The Corophium volutator beds are plateau-like elevations, where the amphipod Corophium volutator and the polychaete Nereis diversicolor consistently attained their highest densities. The sediment is extremely stable. The surface is sealed with a mucuous layer produced by cyanphytes and diatoms. The densily packed tubes built by $C$. volutator and Pygospio elegans give a firm structure to the upper $2 \mathrm{~cm}$. In summer there are up to 10 vertical tubes $\mathrm{cm}^{-2}$ ! Burrowing species are absent, with the only exception being nemerteans, especially Tetrastemma melanocephalum which prey on C. volutator (Bartsch, 1973). The elevated beds have sharp boundaries bordering on the surrounding Arenicola marina flats. The distinct border is demonstrated in Figure 4. However, the position of the border may vary temporally. When $C$. volutator and P. elegans dwindle, the niveau of the sediment surface becomes adjusted to the low level of the Arenicola marina flats. For example, the seaward boundary of a Corophium volutator bed fell back $80-100 \mathrm{~cm}$ within three weeks (August 28, to Sept. $17,1974)$. The cause of which remains uncertain.

Table 1

Epifaunal and infaunal abundance in patches of dense and scattered growth of the small eelgrass Zostera noltii: 10 samples $\left(25 \mathrm{~cm}^{2}\right.$ and $5 \mathrm{~cm}$ deep) were examined from each type on August 19,1975 , numbers $250 \mathrm{~cm}^{-2}$

\begin{tabular}{|lcc|}
\hline Macrofauna & $\begin{array}{c}\text { Low density } \\
\text { of eelgrass }\end{array}$ & $\begin{array}{c}\text { Dense patches } \\
\text { of eelgrass }\end{array}$ \\
\hline More abundant in areas of scattered growth: & & 41 \\
Pygospio elegans (< $5 \mathrm{~mm}$ 1.) & 93 & 7 \\
Indifferent: & 12 & 104 \\
Macoma baltica & 74 & 15 \\
Peloscolex benedeni & 17 & 238 \\
Scoloplos armiger $(>15 \mathrm{~mm}$ 1.) & 204 & 1686 \\
Pygospio elegans ( $>5 \mathrm{~mm}$ 1.) & & 18 \\
More abundant in dense patches: & 710 & 52 \\
Hydrobia ulvae & 1 & 51 \\
Littorina (2 spp.) & 14 & 163 \\
Polydora ligni & 17 & 13 \\
Malacoceros fuliginosus & 53 & 12 \\
Capitella capitata & - & 9 \\
Micropbthalmus spec. & 3 & 1705 \\
Scoloplos armiger $(<15 \mathrm{~mm} 1)$. & 1 & 722 \\
Nemertini (2 spp.) & 716 & \\
\hline Total: epifauna & 502 & \\
Total: infauna & & \\
\hline
\end{tabular}


The eelgrass bed forms a sharply defined boundary with the Arenicola marina flat as well. The burrowing processes of the lugworm are hampered by the meshwork of Zostera roots, while the small eelgrass cannot establish itself in a sediment with constantly reworked top layers. The leaves of $Z$. noltii are no longer than $15 \mathrm{~cm}$ with a width of $1 \mathrm{~mm}$. From July to November they form a dense cover but in the rest of the year their coverage is very poor. The rootlets form a dense meshwork which penetrates down to a depth of $10 \mathrm{~cm}$. Important eelgrass grazers are brent geese Branta bernicla $\mathrm{L}$. To get at the roots they dig numerous craters equal to their size, which

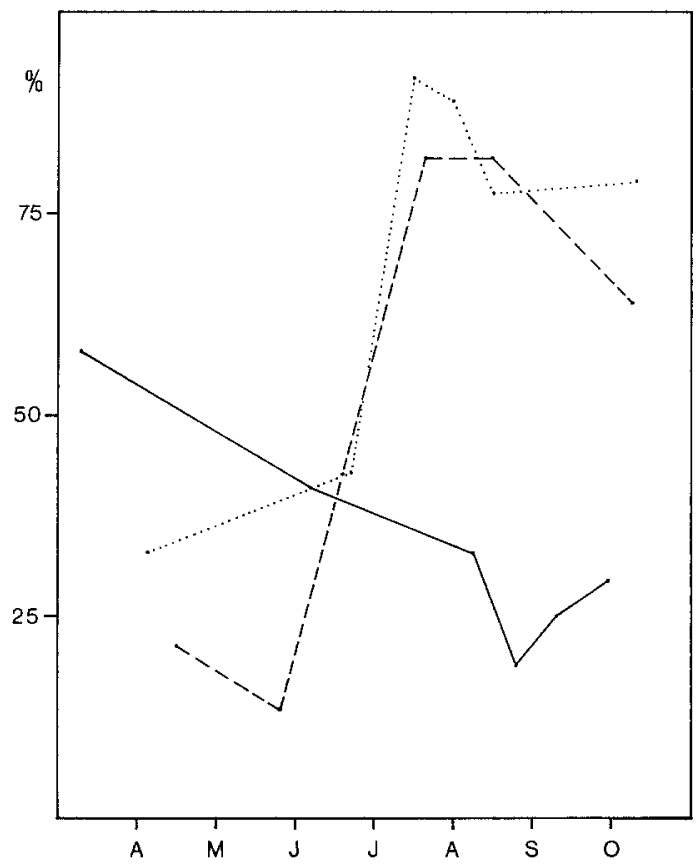

Fig. 5: Percentages of juvenile Pygospio elegans (length $<5 \mathrm{~mm}$ ) from spring to autumn 1975 in the eelgrass bed (straight line), sand flat (broken line), and mud flat (dotted line)

cause the grass bed to look like a shell-pitted area. This happens in late autumn and in winter. Besides causing damage to the tube-building infauna (i. e. P. elegans) by grubbing up the sediment, this causes a mosaik-like pattern, and thus raises the heterogeneity of the habitat. The density of the eelgrass significantly affects the composition of the macrofauna (Table 1). Not only snails crawling on the leaves are more numerous in the dense patches but infaunal species as well. In Scoloplos armiger only juveniles are significantly more abundant within the eelgrass patches, while juvenile $P$. elegans favour the patches with scattered growth.

A remarkable feature of the animal assemblage dwelling among eelgrass are the deviating population structures found in many species when compared to the adjacent tidal flats. The percentage of juvenile $P$. elegans decreases from spring to autumn in the grass bed, while increasing in the sand and mud flats (Fig. 5). Ampharete acutifrons 
experienced low mortality in the eelgrass bed and matured in its second year. In the mud flat, however, it suffered high mortality but showed fast growth, and maturation was achieved in its first year. The population of Cerastoderma edule was composed of several age-classes. All other cockle beds in the area originated from a spatfall in 1970.

The appearance of the extensive $s$ a $\mathrm{d} f \mathrm{lats}$, positioned between the eelgrass zone and the mussel banks, is shaped by the lugworm Arenicola marina. The sediment is very unstable and the top layer is easily resuspended. In an experiment $I$ forced the lugworm to leave three plots of $2500 \mathrm{~cm}^{2}$ each, using a fine meshed gauze implanted

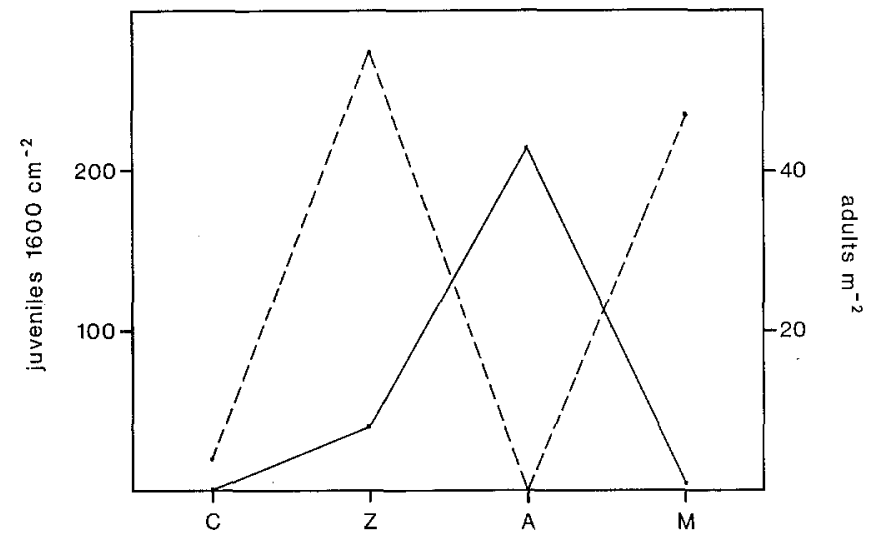

Fig. 6: Contrary course in abundance of juvenile (length $<10 \mathrm{~mm}$; broken line) and adult (length $>60 \mathrm{~mm}$; straight line) Arenicola marina along the transect in March/April 1975; $\mathrm{C}=$ Corophium bed, $\mathrm{Z}=$ Zostera bed, $\mathrm{A}=$ Arenicola flat, $\mathrm{M}=\mathrm{mud}$ flat

horizontally in the sediment at a depth of $5 \mathrm{~cm}$, without disturbing the stratification. The gauze inhibited the construction of funnels and closed the tail shafts of the lugworm's tube. Within one week the surface area above the gauze was covered by a conspicuous film of diatoms, clearly indicating that it was the lugworm who prevented extensive diatom growth. Still there is a high density of the tube-building spionid $P$. elegans between the funnels and casts formed by the lugworm. Frequently it could be observed that tubes hurl down the funnels, however, this does not seem to harm the population as a whole.

In this sand flat the $A$. marina population was devoid of any juveniles. An investigation in spring revealed a negative relationship between the abundance of $O$ group and adult worms along the transect (Fig. 6). Most likely, the steady reworking of the sediment by the dense population of adults prevents the settlement of juveniles. Maintenance of the dense population in this sand flat depends on the immigration of grown up $A$. marina from adjacent habitats.

The $\mathrm{mud} \mathrm{flats}$ between the mussel banks are composed of soft fine silt and clay. The stratification of the sediment is very stable and the surface is covered by a thick mat of diatoms. Early in summer, periwinkles leave the mussel banks to graze on these diatoms. In autumn, when it gets stormy, they return to the banks. Except for the deep-dwelling capitellid Heteromastus filiformis and its predator Nephtys bom- 
bergi, only small-sized members of the macrofauna populate these flats. The numerical dominants are $P$. elegans and Peloscolex benedeni. The composition of this assemblage changes drastically throughout the year. In most species minimum abundance occurs in autumn. The cockle $C$. edule is able to maintain dense populations in the sand flats as well as in the mud flats. In 1974 the mudflat population had a density of 100 cockles $\mathrm{m}^{-2}$. The following spring, however, all had died. Like in all other beds in Königshafen, these cockles stem from a spatfall in summer 1970. The only exceptions are those in the grassy area. In the sand and mud flats, juveniles were almost always present, but vanished before attaining a shell length of $2 \mathrm{~mm}$. Among the eelgrass roots some juveniles survive each year.

\section{Description of infaunal assemblages: numerical analysis}

I am well aware of the shortcomings of a numerical approach. But since ecologists are used to such caricatures of species assemblages, this brief analysis may provide some helpful informations.

The constancy of species refers to the steadyness of occurrence in a set of parallel samples. For graphical representation the species are subdivided into five constancy-classes, and the number of species assigned to each class is plotted (Fig. 7). In all four assemblage types investigated, species with a high degree of constancy outnumbered the others, this being less pronounced in the eelgrass bed. A medium degree of constancy is characteristic for species either with patchy distributions or with large sized individuals occurring at low densities. In comparing the four distributions of species constancy, the species composition in the grass bed appears to be heterogeneous (mosaic-like pattern), while the other assemblages are more or less homogeneous, most of all the Corophium volutator bed.

Cumulative species-a rea curves show the relationship between species number and the size of an area (Fig. 8). For each discrete assemblage there is a specific minimum area which includes all the species, except the accidental ones. In the Corophium volutator bed such an area is as small as $700 \mathrm{~cm}^{2}$, and the whole area sampled contained no more than 15 species. In the Zostera noltii bed this minimum area is twice that size and the total number of species is 32. Both species assemblages are discrete, the first one monotonous, the latter of a diversified patchy structure with a high species capacity. The other two assemblages do not appear to be discrete. Even a sample size of $1600 \mathrm{~cm}^{2}$ is not sufficient to include all species. These flats are open to further immigrants. When the species-area curves are transformed to log-normal, with the area on the log-scale, then bimodal distributions are indicated for the eelgrass bed and the sand flat, regardless of the sequence of samples. In the eelgrass bed this correlates with patches of dense and scattered grass cover, in the sand flat with funnels and casts of the lugworm as one sub-habitat and the spaces in between as another. For the mud flat and the Corophium volutator bed the transformed species-area curves indicate unimodal distributions.

Seasonal variations in mean $\mathrm{s}$ pecies de nsit y $100 \mathrm{~cm}^{-2}$ are given in Figure 


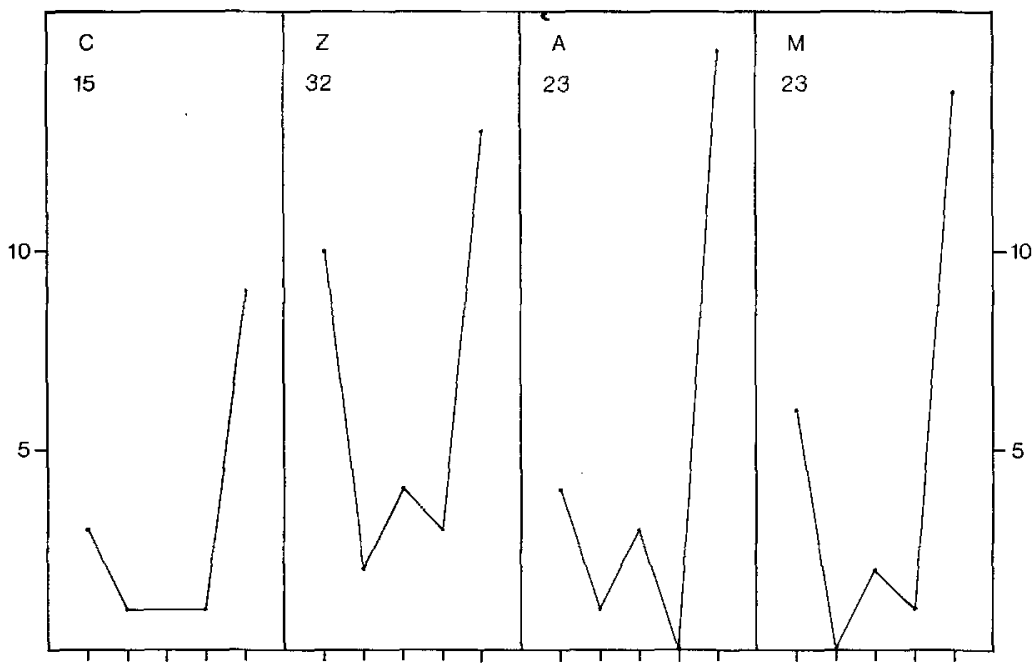

Fig. 7: Curves of species constancy given for spring 1975, based on 16 samples each; along the abcissa the degree of constancy is increasing from left to right for each curve, the number of species assigned to constancy classes is indicated on the ordinate, the total of species 1600 $\mathrm{cm}^{-2}$ is given in the top of each section; C, Z, A, M as in Figure 6

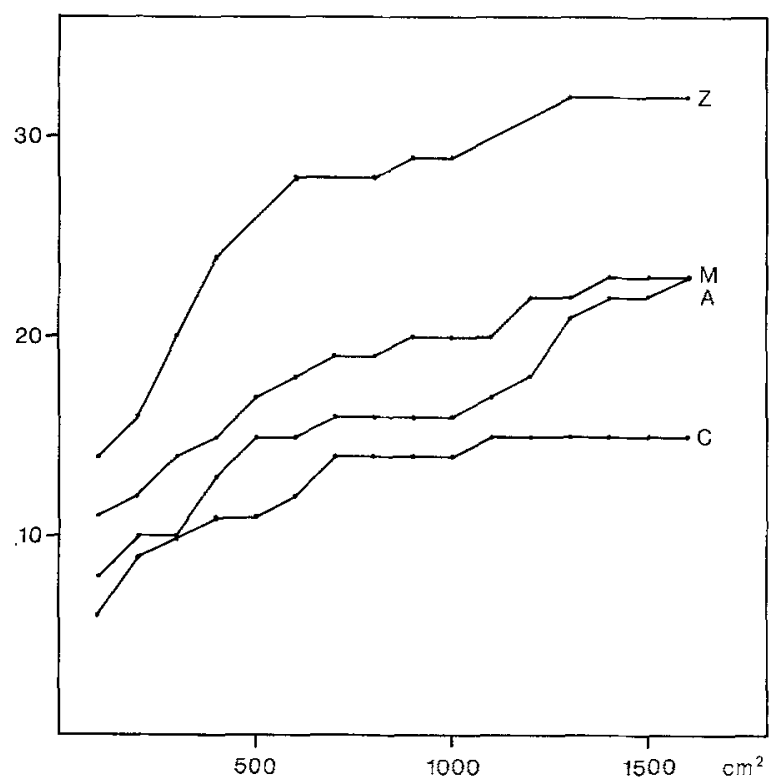

Fig. 8: Cumulative species-area curves given for spring 1975, based on 16 samples each; the number of species is indicated along the ordinate; $C, Z, A, M$ as in Figure 6 
9. In spring and summer the four assemblages can be arranged as followed: Coropbium volutator bed, Arenicola marina flat, mud flat, grass bed, according to increasing areal species richness. The overall high species density in summer is due to the wide dispersal of juveniles. In autumn, species richness falls off again, in the mud flat to such an extent, that this assemblage is now even lower in species density than the Coropbium volutator bed. Thus, in terms of species abundance the mud flat assemblage is less persistent than the others.

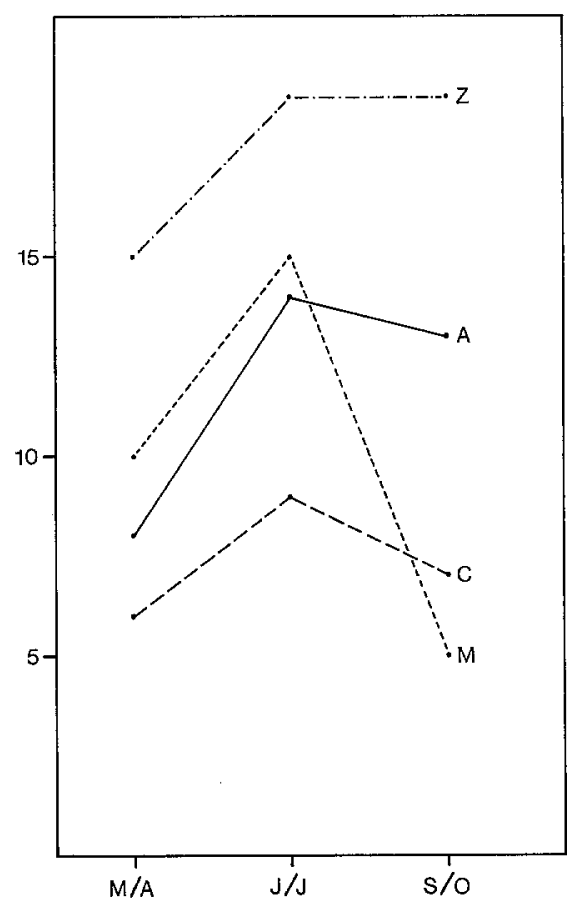

Fig. 9: Mean species density $100 \mathrm{~cm}^{-2}$ in spring, summer and autumn 1975, the number of species is indicated along the ordinate; $\mathrm{C}, \mathrm{Z}, \mathrm{A}, \mathrm{M}$ as in Figure 6

Dom in a nce curves refer to the distribution of individuals among the species. In Figure 10 the six most abundant species are ranked according to their individual numbers on the abcissa, and the percentage of the total abundance is plotted. In spring, all four assemblages are numerically dominated by one species, comprising about $50 \%$ of the total. C. volutator in the Corophium bed, Hydrobia ulvae in the eelgrass bed, $P$. elegans in the Arenicola marina flat as well as in the mud flat. The more pronounced the decline of the dominance curve, the lower the degree of diversity. In the Corophium volutator bed already the fifth species comprises no more than $1 \%$ of the total. In the other assemblages the decline is less abrupt. In the Arenicola marina flat the species that ranked in the fourth position still has more than $10 \%$. As judged from these curves, this is the assemblage with the highest diversity in respect to the distribution of individuals among the species. The Coropbium volutator bed is the 


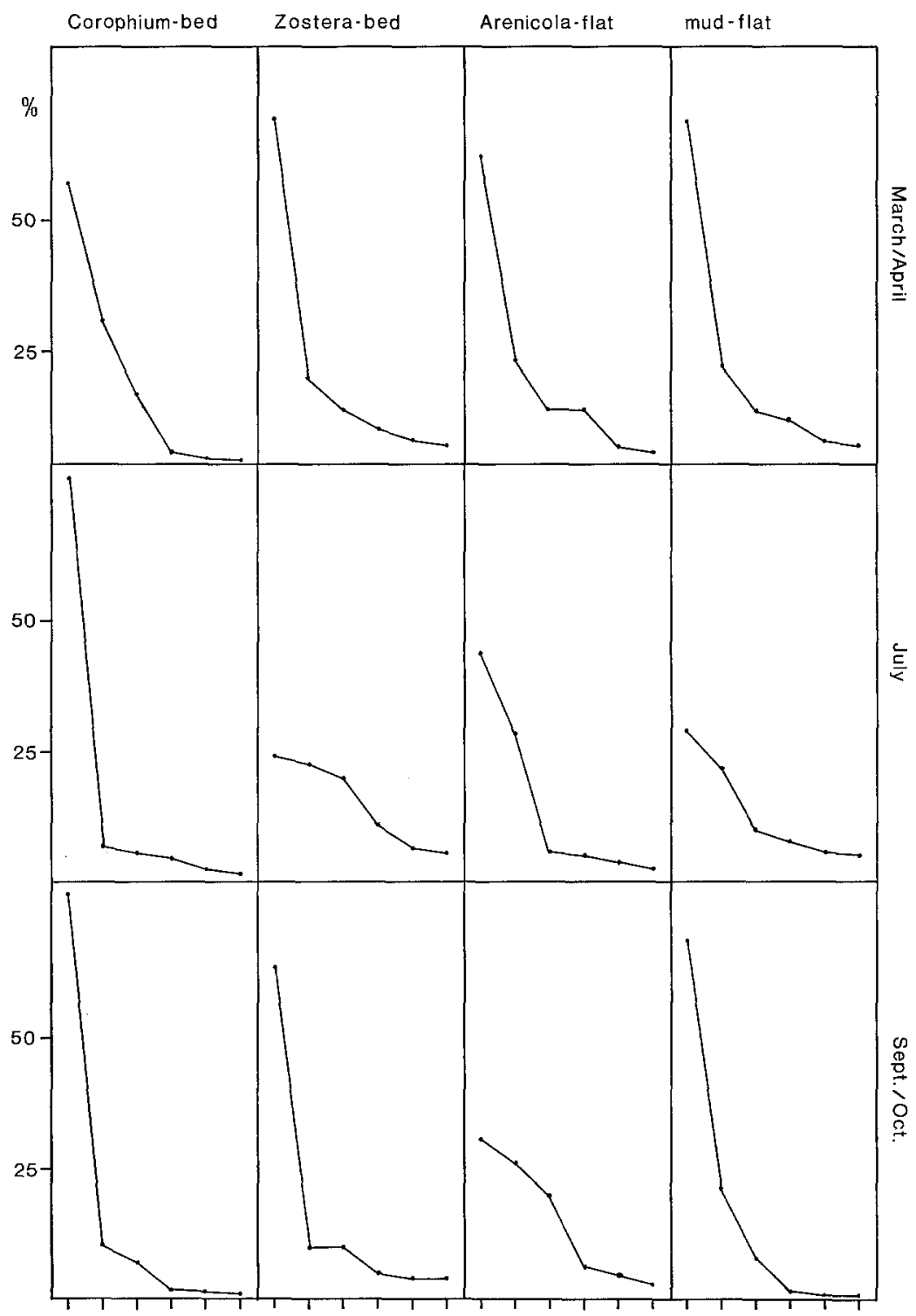

Fig. 10: Dominance curves for spring, summer and autumn 1975, the six most abundant species in each assemblage are ranked from left to right along the abcissa, and their respective percentage of the total is indicated on the ordinate

most monotonous one, even more so in summer and autumn because of an increase in abundance of the dominating species.

In summer, the assemblages in the Zostera noltii bed and in the mud flat are characterized by a different type of dominance curves. The percentage of the domina- 
Table 2

Ranks of the six most abundant species within four macrofaunal assemblages in spring (sp), summer (su) and autumn (au)

\begin{tabular}{|c|c|c|c|}
\hline Macrofaunal assemblages & $\mathrm{sp}$ & su & $\mathrm{au}$ \\
\hline $\begin{array}{l}\text { Bed of Corophium volutator: } \\
\text { Corophium volutator } \\
\text { Hydrobia ulvae } \\
\text { Nereis diversicolor } \\
\text { Pygospio elegans } \\
\text { Arenicola marina (juv.) } \\
\text { Polydora ligni } \\
\text { Macoma baltica } \\
\text { Fabricia sabella }\end{array}$ & $\begin{array}{l}1 \\
2 \\
3 \\
4 \\
5 \\
6\end{array}$ & $\begin{array}{l}1 \\
2 \\
4 \\
3\end{array}$ & $\begin{array}{l}1 \\
2 \\
3 \\
6\end{array}$ \\
\hline $\begin{array}{l}\text { Bed of Zostera noltii: } \\
\text { Hydrobia ulvae } \\
\text { Fabricia sabella } \\
\text { Pygospio elegans } \\
\text { Peloscolex benedeni } \\
\text { Capitella capitata } \\
\text { Arenicola marina (juv.) } \\
\text { Scoloplos armiger } \\
\text { Polydora ligni } \\
\text { Malacoceros fuliginosus }\end{array}$ & $\begin{array}{l}1 \\
2 \\
3 \\
4 \\
5 \\
6\end{array}$ & $\begin{array}{l}1 \\
5 \\
3 \\
6 \\
4\end{array}$ & $\begin{array}{l}2 \\
4 \\
3\end{array}$ \\
\hline $\begin{array}{l}\text { Sandy flat with Arenicola marina: } \\
\text { Pygospio elegans } \\
\text { Scoloplos armiger } \\
\text { Peloscolex benedeni } \\
\text { Capitella capitata } \\
\text { Micropbthalmus spec. } \\
\text { Tharyx marioni } \\
\text { Hydrobia ulvae (juv.) } \\
\text { Spio filicornis } \\
\text { Anaitides mucosa } \\
\text { Cerastoderma edule (juv.) }\end{array}$ & $\begin{array}{l}1 \\
2 \\
3 \\
4 \\
5 \\
6\end{array}$ & $\begin{array}{l}4 \\
5 \\
6\end{array}$ & $\begin{array}{l}1 \\
6 \\
5 \\
4\end{array}$ \\
\hline $\begin{array}{l}\text { Mud flat: } \\
\text { Pygospio elegans } \\
\text { Peloscolex benedeni } \\
\text { Tharyx marioni } \\
\text { Arenicola marina (juv.) } \\
\text { Scoloplos armiger (juv.) } \\
\text { Heteromastus filiformis } \\
\text { Hydrobia ulvde (juv.) } \\
\text { Capitella capitata } \\
\text { Cerastoderma edule (juv.) }\end{array}$ & $\begin{array}{l}1 \\
2 \\
3 \\
4 \\
5 \\
6\end{array}$ & $\begin{array}{l}5 \\
3 \\
6\end{array}$ & $\begin{array}{l}4 \\
1 \\
5\end{array}$ \\
\hline
\end{tabular}

ting species is only half the spring value. The sigmoid-like shape of the curve indicates high species diversity. The main cause is the arrival of juveniles at that time. In the autumn the same phenomenon shows up in the Arenicola marina flat, while in the grass bed and in the mud flat species diversity has dropped again. The mud flat assemblage becomes exceedingly monotonous, dominated by Peloscolex benedeni and Heteromastus filiformis.

Such descriptions of seasonal changes in species density and dominance distribution are worthless without knowledge of the qualitative changes in the assemblages. 
Table 3

Distribution of species within 16 samples of $100 \mathrm{~cm}^{2}$ each, obtained in spring 1975 from the four assemblages. None of the abundant species shows a regular distribution, only a few a random pattern, while for most of them a clumped dispersion is indicated by Lloyd's index of patchiness, given at two levels of significance: $* 0.05>p>0.001$ and $* * p<0.001$ of the Chi-square distribution

\begin{tabular}{|c|c|c|c|}
\hline Macrofaunal assemblages & random & \multicolumn{2}{|c|}{ clumped } \\
\hline $\begin{array}{l}\text { Corophium volutator bed: } \\
\text { Nereis diversicolor } \\
\text { Pygospio elegans } \\
\text { Corophium volutator } \\
\text { total infauna } \\
\text { Hydrobia ulvae }\end{array}$ & + & $\begin{array}{l}* \\
+\end{array}$ & + \\
\hline $\begin{array}{l}\text { Eelgrass bed: } \\
\text { Scoloplos armiger } \\
\text { Malacoceros fuliginosus } \\
\text { Pygospio elegans } \\
\text { Ampbarete acutifrons } \\
\text { Fabricia sabella } \\
\text { Arenicola marina (juv.) } \\
\text { Peloscolex benedeni } \\
\text { total infauna } \\
\text { Hydrobia ulvae }\end{array}$ & + & + & $\begin{array}{l}+ \\
+ \\
+ \\
+ \\
+ \\
+ \\
+\end{array}$ \\
\hline $\begin{array}{l}\text { Arenicola marina flat: } \\
\text { Scoloplos armiger } \\
\text { Peloscolex benedeni } \\
\text { Pygospio elegans } \\
\text { Capitella capitata } \\
\text { total infauna. }\end{array}$ & $\stackrel{+}{t}$ & & + \\
\hline $\begin{array}{l}\text { Mud flat: } \\
\text { bivalve spat } \\
\text { Scoloplos armiger (juv.) } \\
\text { Capitella capitata } \\
\text { Heteromastus filiformis (juv.) } \\
\text { Heteromastus filiformis (ad.) } \\
\text { Pygospio elegans } \\
\text { Tharyx marioni } \\
\text { Arenicola marina (juv.) } \\
\text { Peloscolex benedeni } \\
\text { total infauna }\end{array}$ & & $\begin{array}{l}+ \\
+ \\
+ \\
+\end{array}$ & $\begin{array}{l}+ \\
+ \\
+ \\
+ \\
+ \\
+ \\
+\end{array}$ \\
\hline
\end{tabular}

Therefore the $\mathrm{rank}$ of $\mathrm{s} \mathrm{pec}$ ie s are given in Table 2. In the Coropbium volutator bed little change occurred throughout the year. In the eelgrass bed the summer brings about some alterations. In autumn drastic changes occur in the sand and in the mud flat, although of different types: in the former new dominants arrive, while in the latter former dominants are reduced severely in number.

Another aspect of diversity is the $\mathrm{d}$ is persion of individuals within the assemblages. The spatial pattern is determined by the structure of the habitat, intraand interspecific relations, by the mode of life, by chance and other things. While the habitat structure is rather homogeneous in the Corophium volutator bed and in the mud flat, the eelgrass occurs in patches, and the Arenicola marina flat consists of three 
spatial components: funnels, casts, and the spaces in between. Generally, the dispersion of individuals shows an extremely complex pattern, demanding equally sophisticated tools to analyse them. Here, I only give a rather coarse screen of the actual pattern: in spring 16 random $100-\mathrm{cm}^{2}$ samples were obtained from each assemblage, and the deviations of the calculated index of patchiness (Lloyd, 1967) from that of a random distribution is indicated in table 3 .

None of the species is distributed regularly. This could have been expected in territorial species distributed over an homogeneous habitat. However, the arrival of the first organism of another species initiates heterogeneity. Hence species with territorial behaviour are more likely to be found in the column "random" of table 3. Among the species listed $N$. diversicolor and $M$. fuliginosus might be territorial ones, while $S$. armiger is continually moving around. Most other species seem to be patchy in distribution.

It is interesting to note that nearly all abundant species of the infauna in the eelgrass bed deviate strongly from a random pattern. When all species are pooled instead, deviation from randomness is weak. This suggests that alternating patches are maintained between species. In the mud flat, deviation from randomness is less pronounced in juveniles than in adults, suggesting that time-dependent, non-random processes generate the pattern.

\section{Description of infaunal assemblages: synthesis}

(1) The Corophium bed is dominated by C. volutator throughout the year. Species capacity and species density are very low, the distribution pattern is monotonous. A sharp biogenic boundary separates this discrete assemblage from the adjacent Arenicola marina flat. The position of the boundary is subject to displacement.

(2) In the Zostera noltii bed the dominance structure changes during summer, however, in autumn the spring situation is re-established. The habitat structure is complex, shows a mosaic-like pattern, and segregation of species patches between micro-habitats is indicated. Species capacity, density and diversity are very high. The eelgrass bed is separated from the adjacent flats by a sharp biogenic boundary. This discrete assemblage is distinguished from those of the other flats by the cover of macrophytes with an associated epifauna.

(3) In the Arenicola marina flat the dominance structure remains the same from spring to summer, with definite changes occurring in autumn. This flat resembles a colonization area with a high rate of immigration associated with a low chance of permanent settlement. Species diversity is relatively high. The population of A. marina is the dominant and persistent component in this assemblage. The lugworms are constantly reworking the sediment, which causes a complex, though unstable, habitat structure.

(4) In the mud flat there is great variability in the species composition and dominance structure. No discrete assemblage emerges. A peculiarity is the drastic decline in species density and abundance toward the autumn.

(5) Taking all structural components into consideration, the species-poor Coro- 
pbium volutator bed and the species-rich assemblage in the eelgrass bed can be regarded as stable (in the sense of persistent composition). The assemblages of intermediate species numbers in the sand and mud flats are unstable. In the sand flat, however, the population of $A$. marina itself is stable.

\section{Exclusion experiments: reliability of the caging method}

A mesh size of $1 \mathrm{~mm}$ was considered sufficient to exclude all predatory species visiting the intertidal flats during either low tide or high tide. However, the exclusion of predators is not the only property of such cages. Others are: (a) trapping of juveniles (small migrating organisms get inside the cage and grow into a size that does not allow them to pass through the mesh a second time), (b) reduction of light intensity, (c) lessening of turbulence favours sedimentation.

(a): Only a few species are apt to get trapped in cages. The prerequisite is a pelagic phase followed soon after by a benthic-stage size too large to pass through the mesh again. This evidently happened to young Hydrobia ulvae and species of Littorina and to Carcinus maenas. (b): Cages set out in the eelgrass bed for periods of six months did not cause any noticeable differences in vigour of plant growth as compared with the surrounding. No increased infestation with fouling diatoms could be detected, which would have been a most sensitive indicator for showing the impaired health of Zostera noltii. (c): The alteration of sediment properties due to suppressed turbulance seems to be of minor importance. Ripplemarks (the fingerprint of currents in the Wadden Sea) went through the cages without being disturbed. No marked increase of sedimentation inside the cages was noticed. However, there is a difficulty in separating the effects on the sediment inherent to the cage itself and those caused by increased faunal densities due to exclusion of predators. For instance, when cockles and lugworms grow in dense settlements they change the properties of the sediment entirely, and so do other organisms.

For a direct test of the cage method, I enclosed shrimp in cages and then compared the infaunal development with that of uncaged conditions, as well as with those in a cage excluding all epibenthic predators. In addition, I made use of cages which accidentally got holes so that crabs and other epibenthic predators could enter. These experiments provide the evidence for the suitability of caging to demonstrate effects of predation in a Wadden Sea.

\section{Enclosing of shrimp Crangon crangon}

Two cages were set up in July in the mud flat area. Initially one of them contained 100 shrimp as predators and the other cage contained none. After two weeks the infauna in the two cages was compared with that of the unchanged mud flat (Table 4). In the cage that excluded all epibenthic predators some of the species had already increased significantly as compared to the uncaged-control (Hydrobia ulvae, 
Table 4

Abundances af macrofauna within $200 \mathrm{~cm}^{2}$ caged and control areas in the mud flat after 15 days (July 18 to August 2, 1975). 100 shrimp Crangon crangon were introduced in one of the $0.25 \mathrm{~m}^{2}$ cages

\begin{tabular}{|lccc|}
\hline Macrofauna & Control area & $\begin{array}{c}\text { Cage with } \\
100 \text { shrimp } \\
\text { enclosed }\end{array}$ & $\begin{array}{c}\text { Cage excluding } \\
\text { all epibenthic } \\
\text { predators }\end{array}$ \\
\hline Peloscolex benedeni & 156 & 155 & 282 \\
Pygospio elegans & 267 & 64 & 353 \\
Tharyx marioni & 64 & 33 & 64 \\
Hydrobia ulvae & 4 & 21 & 248 \\
Bivalve spat & 8 & 15 & 16 \\
Heteromastus filiformis & 50 & 43 & 64 \\
Other species & 60 & 24 & 69 \\
Total & 608 & 355 & 1096 \\
Species density & 14 & 14 & 18 \\
\hline
\end{tabular}

bivalve spat, Peloscolex benedeni and Pygospio elegans). In the two annelids the increase was due mainly to yong individuals smaller than $5 \mathrm{~mm}$ in length. The young mud snails presumably were trapped by the cages when they came afloat on the surface film of the water. In the other cage, shrimp reduced almost all the infauna down to a level equal to or even lower than the control. As shrimp are well known as predators of bivalve spat it was puzzling to find that in the cage they left it unmolested. The only explanation is switching: in preying on the more accessible Hydrobia spat the shrimp paid no further attention to the young bivalves. Of the oligochaete $P$. benedeni individual numbers were diminished by the shrimp down to a density equal to the control. This does not imply that the caging effect is virtually reversed.

Table 5

Distribution of size classes in Peloscolex benedeni under uncaged conditions, under intensive predation by shrimp, and when all epibenthic predators are excluded. Numbers $200 \mathrm{~cm}^{-2}$ (for further information see Table 4)

\begin{tabular}{|cccc|}
\hline Length (mm) & Control area & $\begin{array}{c}\text { Cage with } \\
\text { shrimp enclosed }\end{array}$ & $\begin{array}{c}\text { Cage excluding all } \\
\text { epibenthic predators }\end{array}$ \\
\hline 55 & 76 & 19 & 144 \\
$<10$ & 16 & 22 & 33 \\
\hline 15 & 64 & 114 & 105 \\
\hline Total & 156 & 155 & 282 \\
\hline
\end{tabular}

When dividing the individuals into three length-classes (Table 5) it becomes apparent that the shrimp preyed almost exclusively on the very small worms while the deepdwelling adults were able to withstand predation. This holds for annelids as a group as well and explains the indifference of the deep-dwelling capitellid $H$. filiformis to caging. This experiment clearly demonstrates that enclosed predators are capable of 
counteracting the protective effect of caging. This is in support of the explanation that differences in faunal density between caged and uncaged areas are caused by differential predation pressure.

\section{Differences between intact and not intact cages}

Four cages were in position in the mud flat from April to October 1975. On July 2 all cages experienced a heavy settlement of juvenile shore crabs. By the end of July, I removed as many crabs as was feasible. In August, three of the cages got holes and were left unmended. Adult shore crabs managed to get inside. All cages were sampled in October, and a comparison is given in Table 6.

Table 6

Abundances of macrofauna within $400 \mathrm{~cm}^{2}$ caged and control areas. Four $1 \mathrm{~mm}$ meshed cages were maintained from April to October 1975 in the mud flat. Only one cage remained intact, the others were invaded by crabs during the summer

\begin{tabular}{|lrrrrr|}
\hline Macrofauna & $\begin{array}{c}\text { Intact } \\
\text { cage }\end{array}$ & A & Cages with holes & Control \\
\hline Cerastoderma edule & 329 & 63 & 70 & 77 & 3 \\
Abra alba & 61 & 4 & - & - & - \\
Peloscolex benedeni & 1102 & 552 & 400 & 356 & 328 \\
Pygospio elegans & 55 & 28 & 8 & 2 & 7 \\
Polydora ligni & 204 & 12 & 4 & 1 & - \\
Malacoceros fuliginosus & 69 & 22 & 48 & 6 & - \\
Micropbthalmus spec. & 38 & 4 & 4 & 1 & - \\
Tharyx marioni & 394 & 144 & 230 & 116 & 3 \\
Capitella capitata & 26 & 10 & 2 & 10 & 37 \\
Heteromastus filiformis & 52 & 40 & 44 & 56 & 96 \\
Other species & 106 & 34 & 22 & 15 & 3 \\
\hline Total & 2436 & 913 & 832 & 640 & 477 \\
Species density & 26 & 20 & 21 & 19 & 9 \\
\hline
\end{tabular}

When compared to the uncaged control; the intact cage showed that faunal density was increased by a factor of five and the species number was almost three times higher. In the not intact cages, however, the abundance was significantly reduced when compared with the intact one. The infauna resembled more the control conditions than those under perfect predator exclusion. The only abundant species, indifferent to caging were again the deep-dwelling capitellids. They even show a tendency to be less abundant in the cages. However, this is not considered significant because of their patchy distribution.

Both experiments confirm the assumption that the main property of the cages is predator exclusion, and not a suppression of turbulence which in turn might have caused changes in sediment and settlement. 


\section{Exclusion experiments: Mud flat area \\ Set of 1-mm meshed cages}

Cages with a mesh size of $1 \mathrm{~mm}$ were placed on the mud flat from June to October 1974, March to June 1975, and July to October 1975; for periods of about three months, one of the cages from spring to summer and the other two from summer to autumn. At the end of each interval species density had increased inside the cages

Table 7

Abundances of macrofauna within $400 \mathrm{~cm}^{2}$ caged and control areas. Four 1-mm meshed maintained from June 13 to October 91974 in the mud flat; * artificially introduced in the cage

\begin{tabular}{|lcc|}
\hline Macrofauna & Control area & Caged area \\
\hline Hydrobia ulvae & 1 & 1 \\
*Littorina littorea & 1 & 13 \\
Juvenile bivalves: & 2 & 189 \\
Cerastoderma edule & 2 & 91 \\
Abra alba & - & 6 \\
Angulus tenuis & 1 & 5 \\
Macoma baltica & - & 4 \\
Spisula subtruncata & 1 & 3 \\
Mya arenaria & 5 & 3 \\
Cerastoderma edule (4 yrs.) & 1 & 157 \\
Pygospio elegans & - & 71 \\
Polydora ligni & - & 19 \\
Malacoceros fuliginosus & 9 & 889 \\
Tharyx marioni & - & 1 \\
Pectinaria koreni & - & 29 \\
Eteone longa & - & 5 \\
Anaitides mucosa & 1 & 5 \\
Nepbtys bombergi & - & 1 \\
Nereis virens & 4 & 92 \\
Micropbthalmus spec. & - & 1 \\
Scoloplos armiger & 7 & 32 \\
Capitella capitata & 52 & 45 \\
Heteromastus filiformis & 65 & 1792 \\
Peloscolex benedeni & - & 5 \\
Carcinus maenas (juv.) & 150 & 3459 \\
\hline Total & 12 & 22 \\
Species density & & \\
\hline
\end{tabular}

(Tables 7, 8, 9). From spring to summer only minor differences developed due to an overall increase in species density in the foud flat. From summer to autumn species density declined drastically in the control area, while the cages preserved the high species density characteristic of the mud flat in summer (Fig. 11). Bivalve spat found within cages was partly composed of species which are alien to such a fine grained sediment (Angulus tenuis), or which are otherwise restricted to the sublittoral (Abra alba, Spisula subtruncata, Venerupis pullastra).

Almost all species increased in individual numbers when protected by cages (Fig. $11)$; in spite of the fact that predatory species of the infauna increased as well. In 
Table 8

Abundances of macrofauna within $400 \mathrm{~cm}^{2}$ caged and control areas: 1-mm meshed cage maintained from March 31 to June 20, 1975 in the mud flat

\begin{tabular}{|c|c|c|}
\hline Macrofauna & Control area & Caged area \\
\hline \multicolumn{3}{|l|}{ Juvenile gastropods: } \\
\hline Hydrobia ulvae & 82 & 18 \\
\hline Littorina littorea & - & 1 \\
\hline L. obtusata & - & 5 \\
\hline L. jugosa & 2 & 3 \\
\hline Hydrobia ulvae (ad.) & - & 1 \\
\hline Littorina littorea (ad.) & 1 & 1 \\
\hline \multicolumn{3}{|l|}{ Juvenile bivalves: } \\
\hline Cerastoderma edule & 20 & 307 \\
\hline Abra alba & 1 & 15 \\
\hline Angulus tenuis & - & 1 \\
\hline Macoma baltica & 28 & 939 \\
\hline Spisula subtruncata & - & 1 \\
\hline Venerupis pullastra & - & 1 \\
\hline Mytilus edulis & 1 & 25 \\
\hline Mya arenaria & 27 & 33 \\
\hline Cerastoderma edule (5 yrs.) & - & 2 \\
\hline Macoma baltica (ad.) & - & 1 \\
\hline Pygospio elegans & 237 & 706 \\
\hline Spio filicornis & 1 & - \\
\hline Polydora ligni & 15 & 104 \\
\hline Malacoceros fuliginosus (juv.) & 15 & 43 \\
\hline Fabricia sabella & 1 & - \\
\hline Ampharete acutifrons (juv.) & 1 & 3 \\
\hline Tharyx marioni & 63 & 203 \\
\hline Eteone longa & 1 & 15 \\
\hline Anaitides mucosa & 1 & 1 \\
\hline Nereis diversicolor (juv.) & 6 & 28 \\
\hline Nephtys hombergi & 3 & 3 \\
\hline Microphthalmus spec. & 1 & 9 \\
\hline Scoloplos armiger (juv.) & 22 & 206 \\
\hline Arenicola marina (juv.) & - & 4 \\
\hline Capitella capitata & 41 & 222 \\
\hline Heteromastus filiformis & 47 & 25 \\
\hline Peloscolex benedeni & 180 & 373 \\
\hline Tetrastemma melanocephalum & 1 & - \\
\hline Coropbium volutator & 29 & 22 \\
\hline Gammarus locusta & - & 1 \\
\hline Carcinus maenas (juv.) & 1 & 7 \\
\hline Total & 828 & 3332 \\
\hline Species density & 21 & 25 \\
\hline
\end{tabular}

autumn 1974 even an adult Nereis virens (about $200 \mathrm{~mm}$ in length) intruded into the cage. Because Cerastoderma edule generated spat throughout the summer, a high settlement took place in each cage. On the other hand, Macoma baltica reproduced only in early summer. This was documented by the high abundance maintained in the cage from April to June. In Tharyx marioni and Peloscolex benedeni alterations caused by cages were moderate from April to June, while very pronounced from July to September; regardless, whether the abundance in the control area was increasing or 
Table 9

Abundances of macrofauna within $400 \mathrm{~cm}^{2}$ caged and control areas: 1-mm meshed cage maintained from July 1 to October 11, 1975 in the mud flat

\begin{tabular}{|lcc|}
\hline Macrofauna & Control area & Caged area \\
\hline Hydrobia ulvae & 1 & 4 \\
Littorina littorea & - & 1 \\
Juvenile bivalves: & 3 & 513 \\
Cerastoderma edule & - & 9 \\
Abra alba & - & 2 \\
Macoma baltica & - & 1 \\
Scrobicularia plana & - & 74 \\
Spisula subtruncata & - & 5 \\
Mytilus edulis & - & 35 \\
Mya arenaria & 7 & 140 \\
Pygospio elegans & 1 & 20 \\
Spio filicornis & - & 213 \\
Polydora ligni & - & 162 \\
Malacoceros fuliginosus & - & 2 \\
Ampbarete acutifrons & - & 2 \\
Lanice conchilega & 3 & 2129 \\
Tharyx marioni & - & 47 \\
Eteone longa & - & 3 \\
Anaitides mucosa & 1 & 2 \\
Nepbtys bombergi & - & 3 \\
Nereis diversicolor & - & 3 \\
Micropbtbalmus spec. & - & 1 \\
Harmothoe sarsi (juv.) & - & 1 \\
Pholoe minuta & - & 1 \\
Scoloplos armiger & 37 & 56 \\
Capitella capitata & 96 & 89 \\
Heteromastus filiformis & 328 & 1222 \\
Peloscolex benedeni & - & 1 \\
Tetrastemma spec. & - & 196 \\
Coropbium volutator & 477 & 4937 \\
\hline Total & 7 & 28 \\
Species density & & \\
\hline
\end{tabular}

decreasing at the time. A similar independence can be observed in Polydora ligni and in Pygospio elegans. For the capitellid $H$. filiformis the cages were of no protection.

From July to September young shore crabs, shrimp and gobies are in maximum numbers in the intertidal zone. At the same time, species number and total abundance of the infauna are rapidly decreasing in the mud flat area (Fig. 11). As for the experiments, differences in abundance between caged and uncaged areas were small in summer but large in autumn. The same holds true for species density. These results indicate that epibenthic predators excert considerable influence on the dynamics of the mud flat infauna.

In another experiment $I$ set up cages with mesh sizes of $0.5,1,2,5$ and $20 \mathrm{~mm}$, designed to show which size classes of epibenthic predators do exert the most intense predation pressure. Cages covered with a nylon net of $20-\mathrm{mm}$ mesh size should only exclude birds and large fish. A mesh size of $5 \mathrm{~mm}$ can only be passed by small juveniles of crabs, shrimp and gobies, while mesh sizes of 2,1 , and $0.5 \mathrm{~mm}$ exclude almost all 


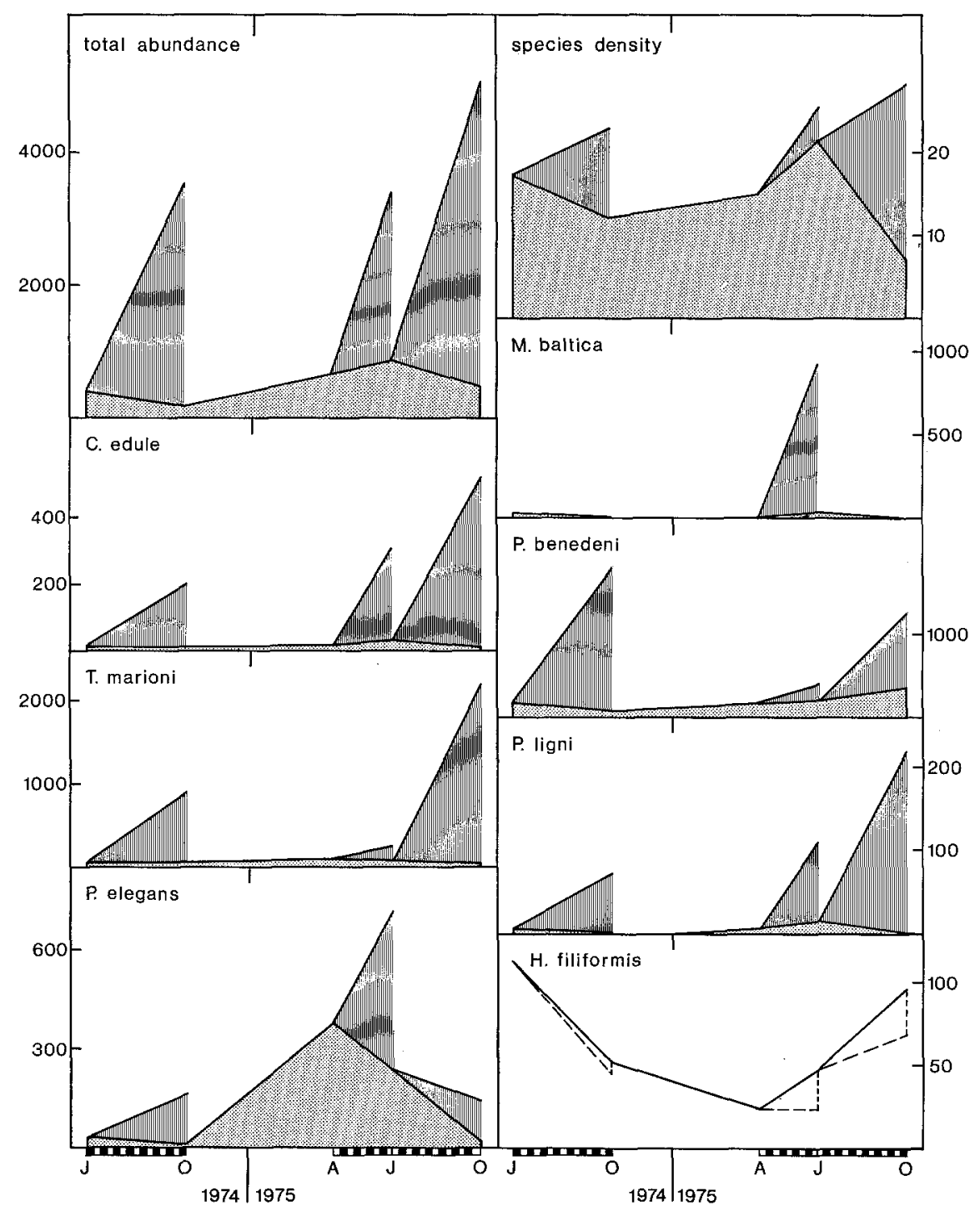

Fig. 11: Alterations in abundance caused by $1-\mathrm{mm}$ meshed cages in the mud flat at three intervals: June to October 1974, April to July 1975, July to October 1975; numbers along the ordinate refer to individuals $400 \mathrm{~cm}^{-2}$, dotted area: natural abundance, striated area: increase caused by cages

epibenthic predators. Three sets of cages with different mesh sizes were positioned on the flat in 1975, from April to July, July to October, and from April to September. Cages with 5-, 2-, 1- and $0.5-\mathrm{mm}$ mesh sizes caused pronounced increases in abundance as compared with the control area. Cages with $20-\mathrm{mm}$ mesh size did not provide any measurable protection. Not all changes in abundances within the cages are directly 
caused by the exclusion of epibenthic predators. Interactions between the enclosed species, and direct effects of the gauze on the settling behaviour are additional components that ought to be considered. The experiments with different mesh sizes offer the opportunity to assess the relative importance of all three components. The results obtained are presented in Tables 10-12.

\section{Set of cages from April to July}

With $20-\mathrm{mm}$ mesh size no protection of the infauna was achieved. On the contrary, some species were even more numerous in the control area, i.e. Macoma baltica and Peloscolex benedeni. I observed that shore crabs preferentially gathered inside these cages, probably to find shelter against bird predation. These crabs preyed more heavily on the infauna within the cage than outside.

\section{Table 10}

Abundances of macrofauna within $400 \mathrm{~cm}^{2}$ caged and control areas: set of cages with different mesh sizes maintained from April to July 1975 in the mud flat

\begin{tabular}{|c|c|c|c|c|c|c|}
\hline \multirow{2}{*}{ Macrofauna } & \multirow{2}{*}{$\begin{array}{c}\text { Control } \\
\text { area }\end{array}$} & \multicolumn{5}{|c|}{ Mesh size $(\mathrm{mm})$ of cages } \\
\hline & & 20 & 5 & 2 & 1 & 0.5 \\
\hline H. ulvae & 82 & 28 & 30 & 50 & 19 & 1696 \\
\hline Juvenile bivalves: & & & & & & \\
\hline M. baltica & 28 & 7 & 717 & 745 & 939 & 923 \\
\hline C. edule & 20 & 16 & 451 & 431 & 307 & 394 \\
\hline$M$ arenaria & 27 & 4 & 52 & . 88 & 33 & 294 \\
\hline M. edulis & 1 & 3 & 19 & 42 & 25 & 101 \\
\hline others (4 spp.) & 1 & - & 4 & 14 & 18 & 5 \\
\hline P. elegans & 237 & 249 & 493 & 609 & 706 & 1413 \\
\hline P. ligni & 15 & 10 & 67 & 94 & 104 & 202 \\
\hline M. fuliginosus & 15 & 14 & 46 & 93 & 44 & 242 \\
\hline T. marioni & 63 & 41 & 65 & 107 & 203 & 121 \\
\hline S. armiger & 22 & 4 & 131 & 55 & 206 & 118 \\
\hline C. capitata & 41 & 48 & 264 & 233 & 222 & 78 \\
\hline P. benedeni & 180 & 98 & 198 & 273 & 373 & 451 \\
\hline Others (25 spp.) & 96 & 102 & 151 & 184 & 134 & 162 \\
\hline Total & 828 & 624 & 2685 & 3125 & 3332 & 6197 \\
\hline Species density & 21 & 22 & 26 & 24 & 25 & 30 \\
\hline
\end{tabular}

From 5-mm mesh size on, protective effects are significant. In the mud flat shrimp and gobies showed up no earlier than June, and the first wave of settlement in the 0-group of shore crabs occurred on July 2. Thus the only important predators in the early season were adult shore crabs and a few fish, and all cages with a 5-mm or smaller mesh should have been sufficient to exclude all epibenthic predation. This was confirmed by the results. There were only insignificant differences between the cages with 5-, 2-, and 1-mm mesh size. The cage covered with $0.5-\mathrm{mm}$ gauze, however, enclosed a divergent assemblage. A spatfall of Hydrobia ulvae got trapped. Spat of two bivalve species - Mya arenaria and Mytilus edulis, both provided with a byssus 
gland - and tube-building spionids attained their highest densities in this cage. Most likely the fine meshed gauze is attractive to them. Moreover, the young bivalves just mentioned attached preferably to the tube-caps of the spionids and thus were no longer endangered by the possibility of sinking in the mud.

Competition almost certainly contributed to the pattern of abundances within cages as well. There is a negative relationship between densities of the burrowing species Capitella capitata and tube-building spionids. In April, when the cages were set up, I recorded 360 juvenile Arenicola marina $2500 \mathrm{~cm}^{-2}$ (size of the cages). None survived in the control area and in the cage with $0.5-\mathrm{mm}$ gauze, but 25 in the $1-\mathrm{mm}, 94$ in the $2-\mathrm{mm}$ and 156 in the $5-\mathrm{mm}$ meshed cages. Again there is a negative correlation to the spionid polychaetes. The mechanism involved might be the constant reworking of the sediment by the fast growing lugworms; thereby disturbing the tube-dwellers. In petri dishes I observed predatory behaviour by Polydora ligni. The high abundance of this species in the $0.5-\mathrm{mm}$ meshed cage might account for the failure of young lugworms to survive in this cage.

In Figure 12 the quantitative results of this set of cages are summarized. There are two major steps of increase in abundance, at the $5-\mathrm{mm}$ and the $0.5-\mathrm{mm}$ meshed

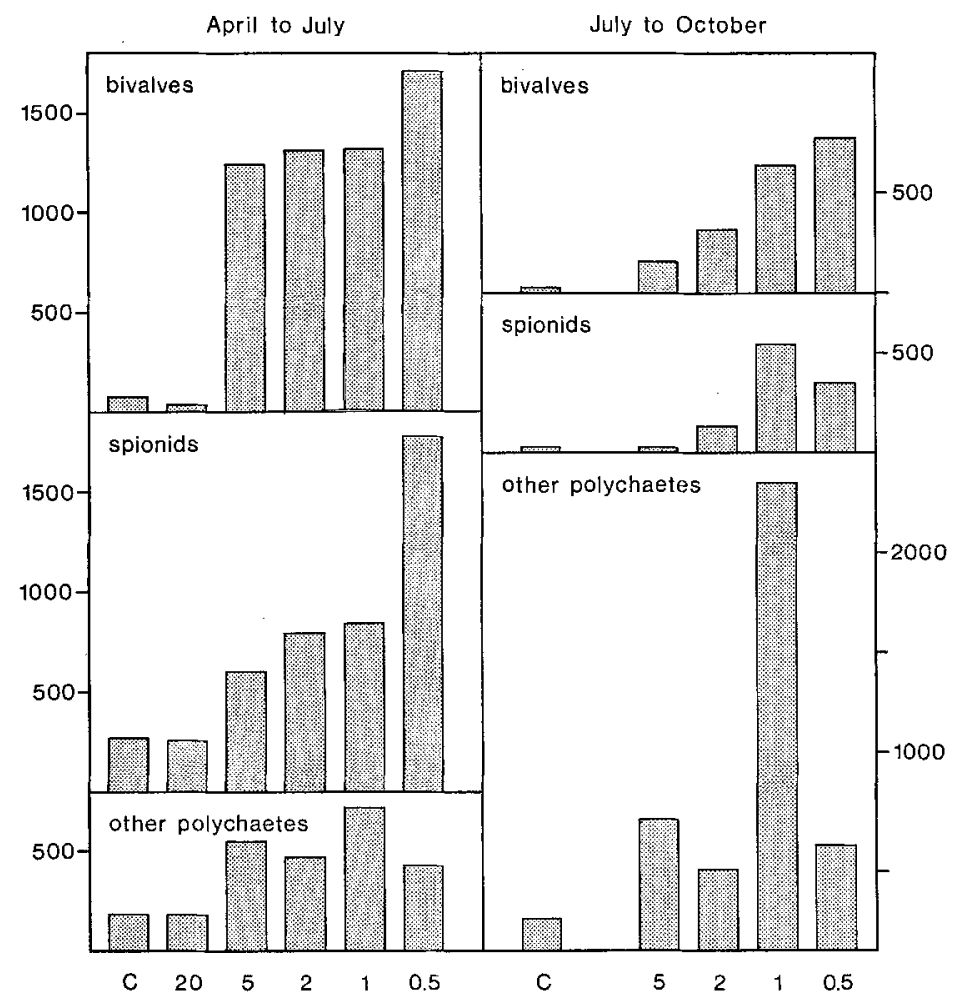

Fig. 12: Infaunal abundance in the mud flat in relation to the mesh size of cages, one set maintained from spring to summer and the other from summer to autumn 1975; numbers along the ordinate refer to individuals $400 \mathrm{~cm}^{-2}$, the mesh size is indicated in $\mathrm{mm}$ on the abcissa, $\mathrm{C}=$ control area 
cages. The first step is a response to the exclusion of epibenthic predators, the second step is induced by the attractiveness of the fine mesh of the gauze to tube-building spionids and to two bivalve species.

\section{Set of cages from July to October}

During this time, flocks of young shore crabs, shrimp and gobies were most abundant on the mud flats. The small stages were able to pass mesh sizes of 5 and $2 \mathrm{~mm}$. Thus no threshold in abundances is to be expected at the $5 \mathrm{~mm}$ cage, rather more a gradual increase up to the 1 -mm meshed cage. In addition, pelagic megalopa of

Table 11

Abundance of macrofauna within $400 \mathrm{~cm}^{2}$ caged and control areas: set of cages with different mesh sizes maintained in the mud flat from July to October 1975

\begin{tabular}{|c|c|c|c|c|c|}
\hline \multirow{2}{*}{ Macrofauna } & \multirow{2}{*}{$\begin{array}{c}\text { Control } \\
\text { area }\end{array}$} & \multicolumn{4}{|c|}{ Mesh size (mm) of cages } \\
\hline & & 5 & 2 & 1 & 0.5 \\
\hline \multicolumn{6}{|l|}{ Juvenile bivalves: } \\
\hline C. edule $<2 \mathrm{~mm} \mathrm{l}$. & 3 & 4 & 144 & 508 & 583 \\
\hline$>12 \mathrm{~mm} \mathrm{l}$ & - & 137 & 121 & 5 & - \\
\hline S. subtruncata & - & 1 & 27 & 74 & 120 \\
\hline M. arenaria & - & 1 & 9 & 35 & 41 \\
\hline others (7 spp.) & - & 2 & 8 & 17 & 31 \\
\hline P. elegans & 7 & - & 10 & 140 & 99 \\
\hline P. ligni & - & - & 102 & 213 & 187 \\
\hline M. fuliginosus & - & 1 & 16 & 162 & 19 \\
\hline T. marioni & 3 & 506 & 349 & 2129 & 473 \\
\hline H. filiformis & 96 & 121 & 33 & 89 & 33 \\
\hline C. capitata & 37 & 17 & 8 & 56 & 17 \\
\hline P. benedeni & 328 & 428 & 294 & 1222 & 1100 \\
\hline C. volutator & - & 1 & - & 196 & - \\
\hline Others (18 spp.) & 4 & 14 & 21 & 101 & 57 \\
\hline Total & 477 & 1233 & 1142 & 4937 & 2760 \\
\hline Species density & 7 & 17 & 22 & 28 & 21 \\
\hline
\end{tabular}

the shore crab entered the cages, metamorphosed, and the benthic juveniles were unuble to leave the fine meshed cages again. In August, no juvenile crabs inside the 0.5$\mathrm{mm}$ meshed cage were observed and only very few in the 1-mm meshed cage. In the 2- and 5-mm meshed cages I found up to 6 little crabs $100 \mathrm{~cm}^{-2}$. In October only the 5 -mm meshed cage still contained young crabs. A few young shrimp were also found in this cage.

The gradual increase in abundance from coarse to fine-meshed gauze is documented in Figure 12. The cockles consist of two distinct size-classes indicating one spatfall in July and one in early September. Cockles from the first spatfall dominated the 5and 2-mm meshed cages, while the second was most successful in the 1 - and $0.5-\mathrm{mm}$ meshed cages. This time the spionids did not outnumber all other annelids in the $0.5-$ $\mathrm{mm}$ meshed cage. In the 1-mm meshed cage Tharyx marioni achieved the tremendous density of 5 individuals $\mathrm{cm}^{-2}$. In July Lanice conchilega settled inside the cages and 
grew up quickly. In the 5- and 2-mm meshed cages I counted 22 occupied tubes, 12 in the $1-\mathrm{mm}$ meshed cage, and none in the $0.5-\mathrm{mm}$ meshed cage. Together with the grown up cockles these large worms were expected to interfere with other inhabitants inside the cage.

\section{Set of cages from April to September}

On July 2 all cages were invaded by megalopa-stages of Carcinus maenas, although in the fine meshed cages only to a minor extent. In September all the cages contained young crabs, some of them already with a carapace width of up to $20 \mathrm{~mm}$. This set of cages should be regarded as a 'Carcinus-inclusion-experiment' than for exclusion. Because of the crabs, the total abundance of the enclosed infauna was less than in the cages maintained from July to September (Table 12). However, the crabs

\section{Table 12}

Abundances of macrofauna within $400 \mathrm{~cm}^{2}$ caged and control areas: set of cages with different mesh sizes maintained in the mud flat from April to September 1975

\begin{tabular}{|lcrrrrr|}
\hline Macrofauna & $\begin{array}{c}\text { Control } \\
\text { area }\end{array}$ & 20 & \multicolumn{5}{c|}{ Mesh size (mm) of cages } \\
\hline H. ulvae & - & - & 2 & - & 3 & 232 \\
L. littorea (juv.) & - & 1 & 1 & 2 & 1 & 63 \\
Juvenile bivalves & 3 & 2 & 18 & 82 & 208 & 179 \\
$\quad$ C. edule & - & 1 & 5 & 9 & 77 & 41 \\
$\quad$ M. baltica & - & 2 & 4 & 1 & 3 & 4 \\
$\quad$ others (3 spp.) & 3 & 3 & 312 & 234 & 237 & 209 \\
T. marioni & 96 & 126 & 33 & 31 & 102 & 81 \\
H. filiformis & 328 & 248 & 370 & 569 & 845 & 1199 \\
P. benedeni & 46 & 19 & 110 & 49 & 124 & 48 \\
Others (18 spp.) & 477 & 402 & 855 & 977 & 1600 & 2056 \\
\hline Total & 77 & 10 & 18 & 21 & 14 & 18 \\
Species density & & & & & & \\
\hline
\end{tabular}

were not able to reverse the protective effects of the cages because some prey organisms had already attained invulnerable sizes before the crabs arrived. This happened with Cerastoderma edule, Macoma baltica, Tharyx marioni (see Table 13), and some others. Among the annelids, Peloscolex benedeni, Heteromastus filiformis, and Tharyx marioni were the least affected, while spionids (with the exception of the deep-dwelling Melacoceros fuliginosus) were severely decimated by the crabs. Almost no cockles from the spatfall early in September withstood predation. The densily packed cockles in the 1 - and $0.5-\mathrm{mm}$ meshed cages measured on the average $17 \mathrm{~mm}$ in length (spatfall in July).

Finally, some remarks on the properties of the sediment enclosed in the cages of different mesh sizes. No general tendency could be detected. In the set of cages maintained on the flat from April to July, the 5-, 2- and 1-mm meshed cages covered a sediment with a light and spongy top layer, oxygenated down to $10 \mathrm{~mm}$, and the surface was at some places raised up to $20 \mathrm{~mm}$ above control level. This must 
have been a result of the reworking activities of the numerous bivalves and burrowing polychaetes. In the $0.5-\mathrm{mm}$ meshed cage the upper layer was more compact and firm, and not raised above control level. Most likely, the firm sediment was caused by the high abundance of tube-building spionids (more than twice as much as in the other cages). The untouched control area showed a firm sediment as well, with an oxygenated layer restricted to the upper $2 \mathrm{~mm}$. In the set of cages maintained from July to

Table 13

Length-classes of Tharyx marioni within an intact and an open 1-mm meshed cage in the mud flat: the cage in position from July to October contained no crabs, while the other in position from April to October was invaded by young crabs during summer; the percentages of three length-classes are given

\begin{tabular}{|ccc|}
\hline Lenght $(\mathrm{mm})$ & Cage without crabs & Cage with crabs \\
\hline$<5$ & 40.0 & 17.1 \\
$5-10$ & 35.5 & 18.6 \\
$>10$ & 24.5 & 64.3 \\
Individuals measured & 2129 & 392 \\
\hline
\end{tabular}

September the upper layer of the enclosed sediments again was light and spongy. This structure and the depth of the oxygenated layer almost certainly took its rise from the densily packed bivalves. Especially, the cockles tended to move around. The 1-mm meshed cage was an exception. Here the top layer even was firmer than in the uncaged flat. The most plausible explanation is the extraordinary high density of the sedentary polychaete Tharyx marioni, 5 to 6 individuals $\mathrm{cm}^{-2}$, that is 4 to 5 times higher than in the other cages.

The surface texture of the enclosed sediments was dependent on the faunal composition as well. Worm casts (most conspicuous were those of the lugworms), numerous polychaete tubes and scars caused by cockle siphons, etc., gave the sediment surface a quite distinct appearance when compared with the control sediment (Fig. 13).

\section{Exclusion experiments: Sand-flat area}

In the middle of April, I placed two 1-mm meshed cages on the extensive sand flat dominated by Arenicola marina. On July 21 one of the cages was sampled and the infauna was compared with that of the control (Table 14). At that time the cages already contained several juvenile crabs. Thus, the composition of the faunal assemblage enclosed by the cage did not resemble purely predation-free conditions. Nevertheless, almost all species outnumbered the control densities by far. The young cockles had already reached a mean length of $4 \mathrm{~mm}$, a size sufficient to be just out of the prey spectrum of the crabs enclosed (carapace width 5-8 $\mathrm{mm}$ ).

On October 14, I sampled the second cage (Table 15). The enclosed crabs had severely decimated the infauna. However, the cockles managed to grow up just in front of the crabs' prey spectrum. In October the mean length of the cockles was 

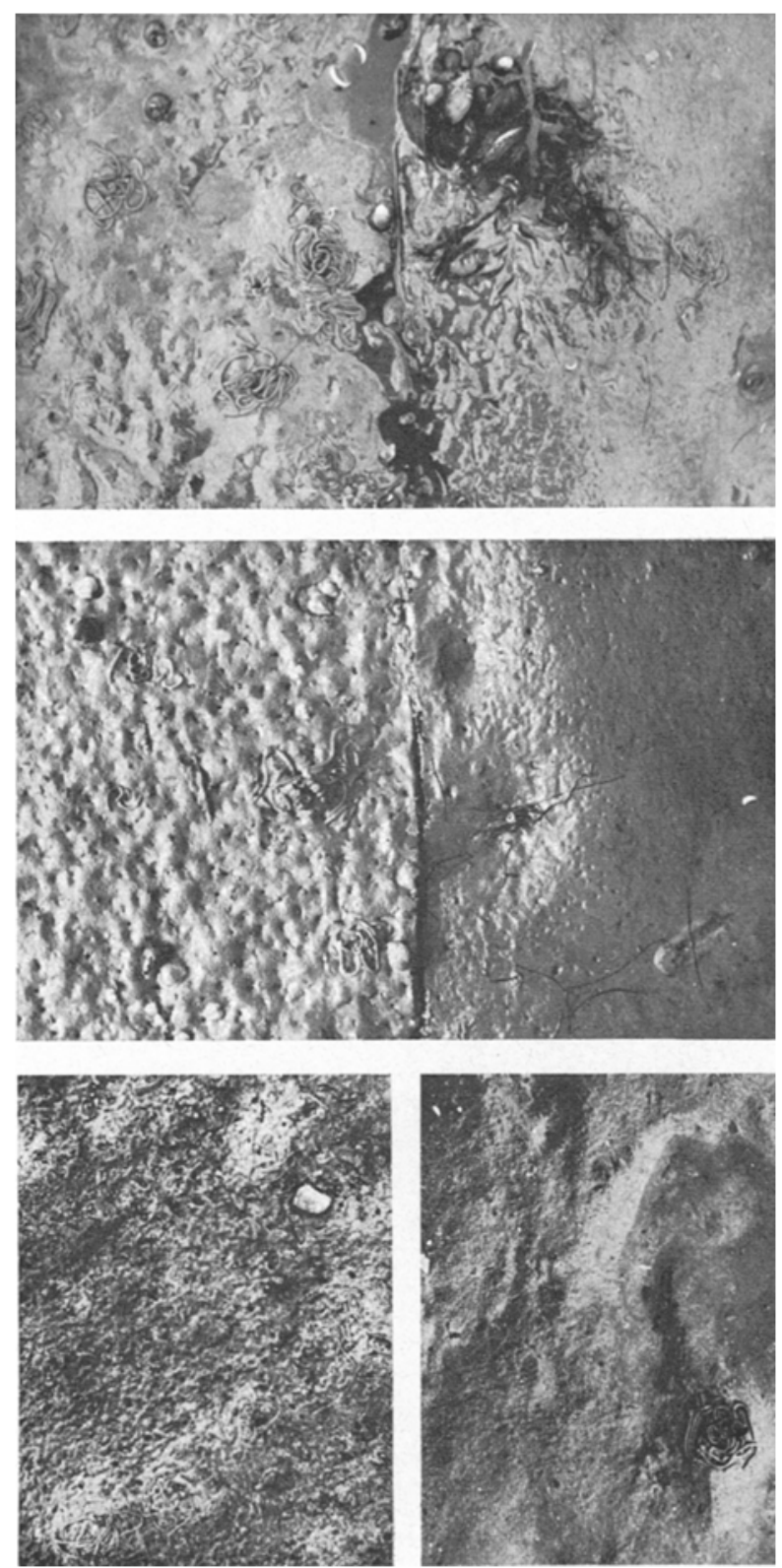

Fig. 13: Surface texture within cages (left side) and of the control area (right side); above: 5-mm meshed cage, April to September, numerous casts from A. marina inside the cage; middle: 2-mm meshed cage, July to September, the scarred surface inside the cage is caused by the siphons of closely packed cockles; below: 1-mm meshed cage, April to July, the granulated surface inside the cage is caused by dense settlements of juvenile tellinids and by tube-caps of small polychaetes 
Table 14

Abundances of macrofauna within $400 \mathrm{~cm}^{2}$ caged and control areas: two 1-mm meshed cages maintained from April 18 to July 21, 1975 in the sand flat dominated by Arenicola marina

\begin{tabular}{|c|c|c|}
\hline Macrofauna & Control area & Caged area \\
\hline Hydrobia ulvae & 21 & 30 \\
\hline Cerastoderma edule (juv.) & 8 & 747 \\
\hline Pygospio elegans & 183 & 764 \\
\hline Spio filicornis & 15 & 21 \\
\hline Tharyx marioni & 8 & 15 \\
\hline Micropbthalmus spec. & 3 & 27 \\
\hline Capitella capitata & 4 & 16 \\
\hline Scoloplos armiger $<30 \mathrm{~mm} 1$. & 115 & 113 \\
\hline$>30 \mathrm{mml}$ & 3 & 8 \\
\hline Peloscolex benedeni & 22 & 35 \\
\hline Carcinus maenas (juv.) & 1 & 26 \\
\hline Others (15 spp.) & 34 & 55 \\
\hline Total & 417 & 1827 \\
\hline Species density & 21 & 22 \\
\hline
\end{tabular}

Table 15

Abundances of macrofauna within $400 \mathrm{~cm}^{2}$ caged and control areas: 1 -mm meshed cage maintained in the sandy flat dominated by the lugworm from April 18 to October 14, 1975

\begin{tabular}{|c|c|c|}
\hline Macrofauna & Control area & Caged area \\
\hline $\begin{aligned} & \text { Cerastoderma edule }<2 \mathrm{~mm} 1 . \\
&>15 \mathrm{~mm} \mathrm{l}\end{aligned}$ & 123 & $\begin{array}{r}30 \\
160\end{array}$ \\
\hline Pygospio elegans & 189 & - \\
\hline Spio flicornis & 161 & - \\
\hline Polydora ligni & 15 & - \\
\hline Tharyx marioni & 14 & 26 \\
\hline Capitella capitata & 38 & 7 \\
\hline Scoloplos armiger & 18 & 1 \\
\hline Peloscolex benedeni & 29 & 36 \\
\hline Others (13 spp.) & 26 & 19 \\
\hline Total & 613 & 281 \\
\hline Species density & 16 & 13 \\
\hline
\end{tabular}

$19 \mathrm{~mm}$, a size making them invulnerable even to the largest crabs of the Wadden Sea. These densily packed cockles left hardly any space in between (Fig. 14). Both, the presence of crabs and the abundant cockles may have caused most species to be less abundant within the cage. The only polychaete species that preponderated was Tharyx marioni.

For the period March to October 1974, I set up a cage covering $25 \mathrm{~m}^{2}$ of the sand flat with a mesh size of $20 \mathrm{~mm}$, a cage designed to protect the infauna against bird and fish predation. However, due to the fact that crabs accepted the cage as a welcome cover, and hiding-place from their predators, no reliable conclusions can be drawn from this experiment. Some species were significantly more abundant inside the cage 

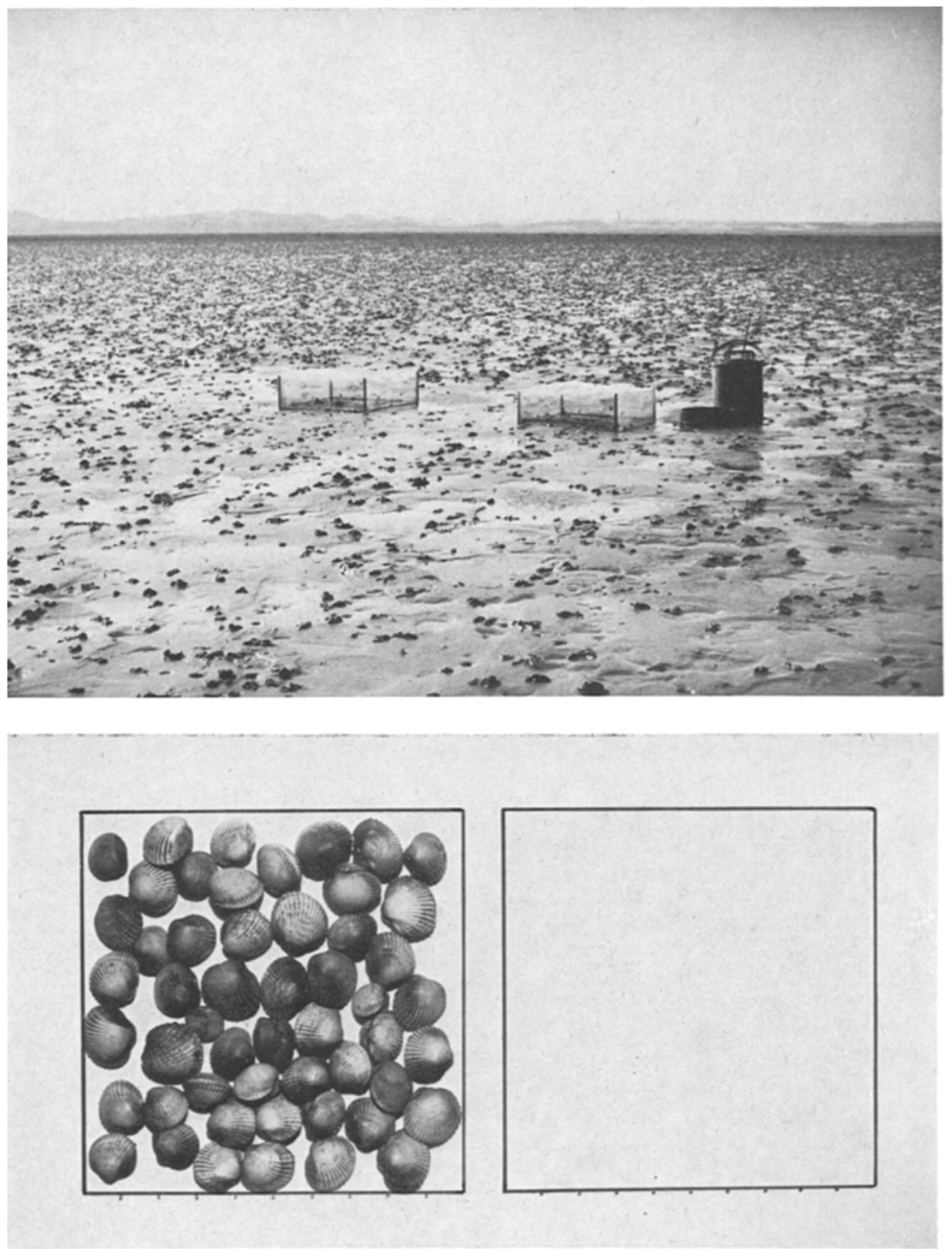

Fig. 14: Caging experiments in the sand flat area; above: two cages with a 1-mm mesh gauze; below: cockles sampled from $100 \mathrm{~cm}^{2}$ inside the cage maintained from April to October, none in the control area

(i.e. Polydora ligni, Malacoceros fuliginosus, Anaitides mucosa), while others were more numerous outside (i.e. Cerastoderma edule and Abra alba smaller than $2 \mathrm{~mm}$, Pygospio elegans, Eteone longa). 
Exclusion experiments: Zostera noltii bed

Two small 1-mm meshed cages, covering an area of only $625 \mathrm{~cm}^{2}$ each, were placed in the eelgrass bed from August 31 to December 16, 1974. The following year I set up cages of the usual size $\left(2500 \mathrm{~cm}^{2}\right)$, from March to June, from March to September and from June to September. The cages did not cause much change in the faunal assemblage (Tables 16, 17, 18). Protective effects were indicated by some species (C. edule, $L$. jugosa and L. littorea, A. mucosa, nemerteans), others were less abundant within cages (small annelids).

A graphical presentation of changes in abundance is given in Figure 15. At a first glance, there seems to be no regular pattern in Hydrobia ulvae. However, this is not

Table 16

Abundances of macrofauna within $400 \mathrm{~cm}^{2}$ caged and control areas: 1-mm meshed cage maintained in the eelgrass bed from August 31 to December 16, 1974

\begin{tabular}{|lrc|}
\hline Macrofauna & Control area & Caged area \\
\hline Hydrobia ulvae & 1259 & 806 \\
Littorina (2 spp.) & 11 & 10 \\
Juvenile bivalves (4 spp.) & 9 & 16 \\
Pygospio elegans & 424 & 356 \\
Malacoceros fuliginosus & 46 & 48 \\
Fabricia sabella & 548 & 764 \\
Capitella capitata & 164 & 104 \\
Scoloplos armiger $<30 \mathrm{~mm} \mathrm{1.}$ & 4 & 22 \\
Anaitides mucosa & 16 & 17 \\
Peloscolex benedeni & 11 & 35 \\
Others (9 spp.) & 196 & 186 \\
Total (without H. ulvae) & 20 & 1572 \\
Species density & 1451 & 20 \\
\hline
\end{tabular}

Table 17

Abundances of macrofauna within $400 \mathrm{~cm}^{2}$ caged and control areas: 1-mm meshed cage maintained in the eelgrass bed from March 9 to June 9, 1975

\begin{tabular}{|lcc|}
\hline Macrofauna & Control area & Caged area \\
\hline Hydrobia ulvae & 487 & 1361 \\
Littorina jugosa & 83 & 264 \\
Macoma baltica (juv.) & 64 & 12 \\
Pygospio elegans & 404 & 443 \\
Fabricia sabella & 133 & 252 \\
Capitella capitata & 216 & 152 \\
Scoloplos armiger & 477 & 313 \\
Peloscolex benedeni & 109 & 61 \\
Nemerteans (3 spp.) & 15 & 17 \\
Others (20 spp.) & 60 & 73 \\
\hline Total (without H. ulvae) & 1548 & 1594 \\
Species density & 28 & 25 \\
\hline
\end{tabular}


Table 18

Abundances of macrofauna within $400 \mathrm{~cm}^{2}$ caged and control areas: 1-mm cages maintained in the eelgrass bed from March to September and from June to September 1975 (two cages each time)

\begin{tabular}{|lrcc|}
\hline \multirow{2}{*}{ Macrofauna } & Control area & March-Sept. & June-Sept. \\
\hline Hydrobia ulvae & 1700 & 1338 & 1123 \\
Littorina jugosa & 9 & 74 & 23 \\
L. littorea & 12 & 30 & 39 \\
Cerastoderma edule & 4 & 36 & 21 \\
Pygospio elegans & 273 & 262 & 30 \\
Polydora ligni & 111 & 22 & 95 \\
M. fuliginosus $\leq 15 \mathrm{~mm} 1$. & 103 & 104 & 23 \\
Scoloplos armiger & 6 & 12 & 12 \\
Capitella capitata & 18 & 17 & 121 \\
Peloscolex benedeni & 271 & 182 & 44 \\
Others (24 spp.) & 129 & 44 & 820 \\
Total (without H. ulvae) & 45 & 1011 & 24 \\
Species density & 981 & 23 & \\
\hline
\end{tabular}

Table 19

Abundances of macrofauna within $1500 \mathrm{~cm}^{2}$ caged and control areas: 20-mm meshed cage maintained in the eelgrass bed from March 31 to October 16, 1974

\begin{tabular}{|c|c|c|}
\hline Macrofauna & Control area & Caged area \\
\hline Hydrobia ulvae & 3986 & 1776 \\
\hline Littorina littorea & 35 & 54 \\
\hline Littorina jugosa & 159 & 212 \\
\hline \multirow{2}{*}{$\begin{aligned} \text { Macoma baltica } & <6 \mathrm{~mm} \mathrm{l} . \\
& >6 \mathrm{~mm} 1 .\end{aligned}$} & 11 & 12 \\
\hline & 17 & 27 \\
\hline Mytilus edulis & 4 & 14 \\
\hline Mya arenaria & 1 & 5 \\
\hline Cerastoderma edule & 6 & 5 \\
\hline Pygospio elegans & 324 & 183 \\
\hline Malacoceros fuliginosus & 86 & 80 \\
\hline Polydora ligni & 21 & 19 \\
\hline Fabricia sabella & 21 & - \\
\hline Capitella capitata & 366 & 324 \\
\hline \multirow{2}{*}{$\begin{aligned} \text { Scoloplos armiger } & <15 \mathrm{~mm} . \\
& >15 \mathrm{~mm} .\end{aligned}$} & 66 & 12 \\
\hline & 85 & 118 \\
\hline Anaitides mucosa & 21 & 32 \\
\hline Lanice concbilega & 2 & 8 \\
\hline Peloscolex benedeni & 735 & 429 \\
\hline Lineus viridis & 3 & 15 \\
\hline Ampbiporus lactifloreus & 7 & 22 \\
\hline Carcinus maenas & 4 & 11 \\
\hline Sagartiogeton viduata & 1 & 26 \\
\hline Others (8 spp.) & 34 & 34 \\
\hline Total (without $H$. ulvae) & 2021 & 1633 \\
\hline Species density $400 \mathrm{~cm}^{-2}$ & 20 & 22 \\
\hline
\end{tabular}


the case. Most larvae hatch out of the cocoons between May and July. These juveniles leave the grass bed and distribute themselves all over the intertidal zone, chiefly below mean tide level. These migrations are carried out on the surface film of the water when the tide is in. This drifting is hampered by the cages. Consequently, in the cage

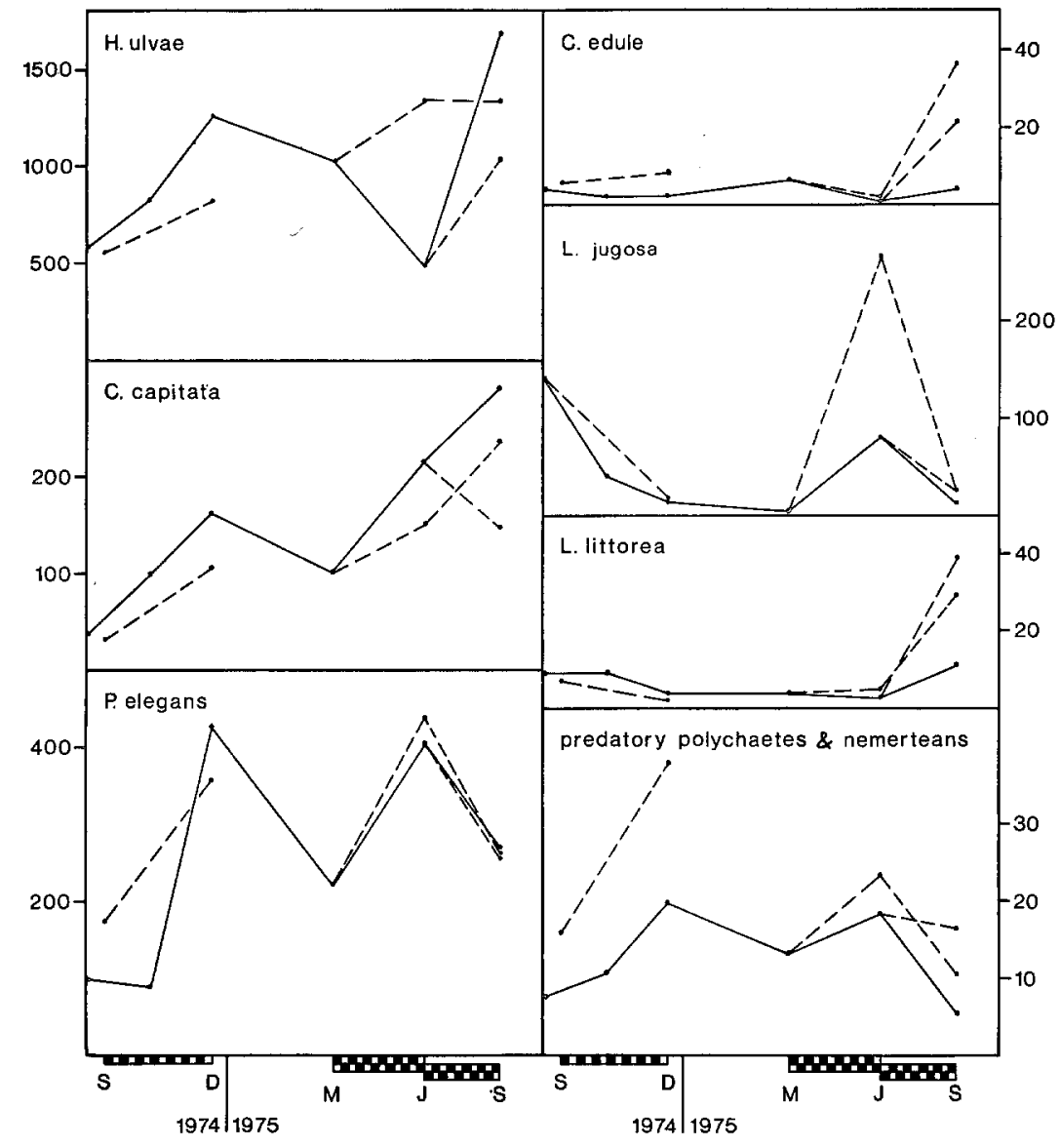

Fig. 15: Alterations in abundance caused by 1-mm meshed cages in the eelgrass bed at four intervals: September to December 1974, March to June, March to September and June to September 1975; numbers along the ordinate refer to individuals $400 \mathrm{~cm}^{-2}$, straight line: natural abundance, broken line: abundance within cages

maintained from March to June juvenile mud snails were highly abundant, and in the cage from March to September this high density was preserved. Cages set up in summer prevented the reestablishment of the young snails drifting back to the eelgrass bed with the advancing season. Trapping of young snails most likely account for the abundances of the two Littorina species as well. Juvenile L. jugosa hatch between March and June, settlement of young L. littorea occurs from June to July. This explains the varying densities inside the different cages. 
In 1975 cockle spat arrived in the seagrass bed no earlier than the beginning of July. Within cages their survival was significantly higher. Spat of Macoma baltica experienced a higher mortality within the cages. Small annelids either showed no difference between caged and uncaged areas or were somewhat less abundant inside. On the other hand, predatory polychaetes and nemerteans were more numerous inside. This was significant, except for the cage maintained from March to June 1975. Prominent among these predators were Anaitides mucosa, Lineus viridis and Amphiporus lactifloreus. The increasing density of predatory species among the enclosed infauna itself presumably decimated small sized annelids.

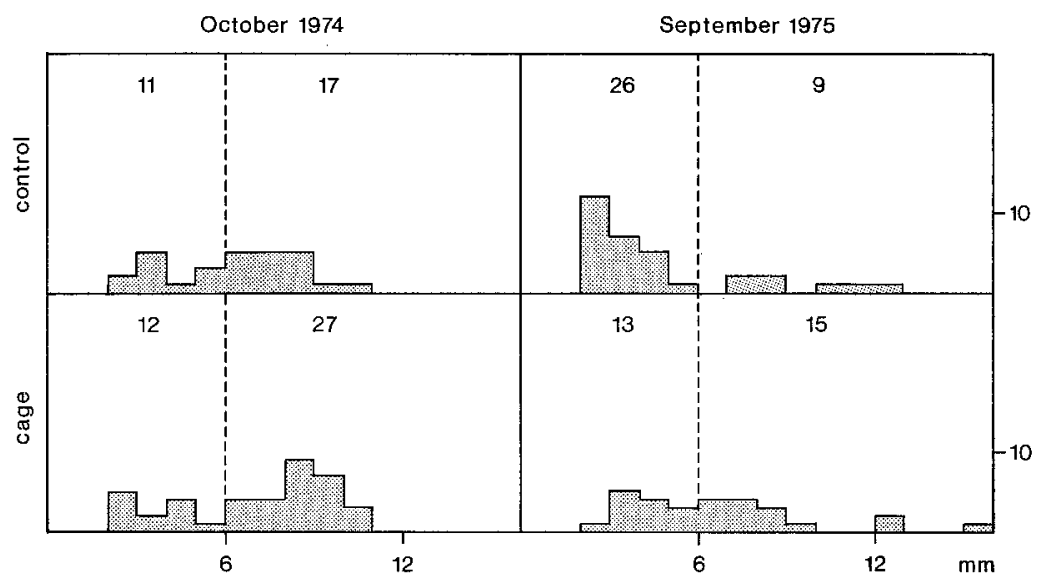

Fig. 16: Size-frequency distributions of Macoma baltica in the uncaged eelgrass bed and within 20-mm meshed cages maintained from March to October 1974 and from March to September 1975; the shell length is indicated along the abcissa, individual numbers along the ordinate and in the top of each section refer to $1500 \mathrm{~cm}^{2}$; differences in abundance of $M$. baltica $\geq 6 \mathrm{~mm}$ in length between control and cages are significant $(\mathrm{p} \leq 0.05)$

Cages with 20-mm mesh size were maintained in the eelgrass belt from March to October 1974 and from March to September 1975, covering areas of 25 or $9 \mathrm{~m}^{2}$ each. Differences in abundance observed between caged and control areas were similar in both years (Tables 19, 20). Large bivalves were protected significantly by these cages. $M$. baltica experienced a better chance of survival within cages as soon as the individuals reached a length of $6 \mathrm{~mm}$ and more (Fig. 16). During summer, juveniles of the mussel $M$. edulis could be found attached to the eelgrass leaves. With increasing size they built themselves nests out of these leaves and out of shells of Hydrobia ulvae and Littorina spp. by means of their byssus gland. Most of them vanished from the unprotected eelgrass bed before October 1974, while in the cage they showed a reasonably good survival. In 1975 even cockles were protected by these large meshed cages. Periwinkles were more abundant in the cages as well. Again there was a tendency for crabs to be more numerous underneath the cages, and this probably caused low abundances in $H$. ulvae. However, because the crabs do find shelter under the eelgrass leaves anyway, the cages are not as attractive to them as in the sand and mud 
flats. Again, small polychaetes were less abundant within cages (i.e. P. elegans, $P$. ligni) or showed no difference (i.e. C. capitata). Juveniles of the polychaete Scoloplos armiger found less favourable conditions in the caged areas than did individuals longer

Table 20

Abundances of macrofauna within $1500 \mathrm{~cm}^{2}$ caged and control areas: 20-mm meshed cage maintained in the eelgrass bed from March 6 to September 13, 1975

\begin{tabular}{|c|c|c|}
\hline Macrofauna & Control area & Caged area \\
\hline Hydrobia ulvae & 6375 & 4748 \\
\hline Littorina littorea & 44 & 88 \\
\hline L. jugosa & 34 & 80 \\
\hline C. edule $<8 \mathrm{~mm} 1$. & 5 & 4 \\
\hline$>8 \mathrm{~mm} 1$ & 10 & 24 \\
\hline M. baltica $<6 \mathrm{~mm} 1$. & 26 & 13 \\
\hline$>6 \mathrm{~mm} 1$. & 9 & 15 \\
\hline Pygospio elegans & 1024 & 551 \\
\hline Polydora ligni & 416 & 83 \\
\hline M. fuliginosus $<15 \mathrm{~mm} \mathrm{l}$. & 385 & 173 \\
\hline$>15 \mathrm{~mm} 1$ & 22 & 24 \\
\hline S. armiger $<15 \mathrm{~mm} 1$. & 11 & - \\
\hline$>15 \mathrm{~mm} \mathrm{l}$ & 56 & 61 \\
\hline Capitella capitata & 1016 & 855 \\
\hline Micropbthalmus spec. & 38 & 8 \\
\hline Ampharete acutifrons & 31 & 28 \\
\hline Anaitides mucosa & 9 & 12 \\
\hline Peloscolex benedeni & 484 & 664 \\
\hline Lineus viridis & 5 & 10 \\
\hline Ampbiporus lactifloreus & 2 & 8 \\
\hline Carcinus maenas (juv.) & 19 & 26 \\
\hline Sagartiogeton viduata & - & 6 \\
\hline Others (13 spp.) & 32 & 29 \\
\hline Total (without $H$. ulvae) & 3372 & 2763 \\
\hline Species density $400 \mathrm{~cm}^{-2}$ & 26 & 26 \\
\hline
\end{tabular}

Table 21

Abundances of juvenile and adult Scoloplos armiger within $1500 \mathrm{~cm}^{2}$ caged and control areas: $20-\mathrm{mm}$ meshed cage maintained in the eelgrass bed from March to October 1974. Abundances between control and cage conditions differ significantly $(p<0.05)$

\begin{tabular}{|lcccc|}
\hline Length $(\mathrm{mm})$ & April & $\begin{array}{c}\text { Control area } \\
\text { July }\end{array}$ & October & $\begin{array}{c}\text { Caged area } \\
\text { October }\end{array}$ \\
\hline$<15 \mathrm{~mm}$ & $-\overline{\mathrm{m}}$ & 335 & 66 & 12 \\
$>15 \mathrm{~m}$ & 156 & 103 & 85 & 118 \\
\hline
\end{tabular}

than $15 \mathrm{~mm}$ (Table 21). As in the 1-mm meshed cages, the increase in infaunal predators like Anaitides mucosa, Lineus viridis and Amphiporus lactifloreus was likely to be the cause for low rates of survival in small annelids. 


\section{Exclusion experiments: Corophium volutator bed}

In the Corophium volutator bed, I installed 1-mm meshed cages from April 21 to July 23, 1975 (Table 22). On July 23, I found the cages damaged and signs of bird predation were already visible inside the cages. In addition, many juvenile crabs invaded these cages in July. This probably caused most species to be less abundant within the caged area, with the only exception being the large-sized, deep-dwelling Nereis diversicolor.

T'able 22

Abundances of macrofauna within $400 \mathrm{~cm}^{2}$ caged and control areas: 1-mm meshed cage maintained in the Corophium volutator bed from April 21 to July 23, 1975

\begin{tabular}{|lcc|}
\hline Macrofauna & Control area & Caged area \\
\hline Hydrobia ulvae & 184 & 219 \\
Macoma baltica (juv.) & 59 & 37 \\
Pygospio elegans & 148 & 104 \\
Fabricia sabella & 41 & 8 \\
Eteone longa & 15 & 3 \\
N. diversicolor $<1 \mathrm{~mm}$ width & 114 & 136 \\
Peloscolex benedeni & 14 & 36 \\
Coropbium volutator & 9 & 10 \\
Carcinus maenas (juv.) & 2083 & 841 \\
Others (4 spp.) & 4 & 4 \\
\hline Total (without C. volutator) & 3 & 585 \\
Species density & 591 & 12 \\
\hline
\end{tabular}

Table 23

Abundances of macrofauna within $1000 \mathrm{~cm}^{2}$ caged and control areas: two 20-mm meshed cages maintained in the Corophium volutator zone from April 2 to November 7, 1974. One cage remained tight all the time, while the other opened its sides when submerged

\begin{tabular}{|lccc|}
\hline Macrofauna & Control area & Semi-closed cage & Caged area \\
\hline H. ulvae $<2 \mathrm{~mm}$ high & 14 & 50 & 40 \\
$>2 \mathrm{~mm}$ high & 52 & 76 & 51 \\
M. baltica $>6 \mathrm{~mm} \mathrm{l.}$ & 43 & 36 & 68 \\
Pygospio elegans & 7 & 6 & 20 \\
Fabricia sabella & 150 & 218 & 168 \\
Capitella capitata & 156 & 693 & 42 \\
Scoloplos armiger & 64 & 104 & 42 \\
Eteone longa & 30 & 44 & 40 \\
Arenicola marina & 36 & 36 & 10 \\
Peloscolex benedeni & 2 & 5 & 14 \\
Nemerteans (2 spp.) & 3518 & 3044 & 1 \\
Corophium (2 spp.) & 2 & 4 & 9 \\
Others (8 spp.) & 14 & 5 & 620 \\
\hline Total (without P. benedeni) & 11 & 12 & 15 \\
Species density 400 cm ${ }^{-2}$ & 581 & 1289 & 14 \\
\hline
\end{tabular}


In another experiment two $20-\mathrm{mm}$ meshed cages were maintained from April to November 1974. Each covered an area of $9 \mathrm{~m}^{2}$. One of the two remained permanently closed, like all other cages mentioned so far, the other opened along the sides during high tide by means of a floating device, allowing flatfish to get inside. However, this semi-closed cage was probably more accessible to large-sized crabs than to flatfish. Because of drifting algae the floating mechanism did not work properly all the time, and I sometimes observed footprints of birds (Tringa totanus L.) inside. Thus, this cage should be regarded as a control instead of an exclosure. During the course of the experiment the Corophium volutator bed changed considerably. Until July nearly all $C$. volutator had vanished, leaving the annelids $P$. benedeni and $P$. elegans as dominant species. In autumn, a further annelid species, Fabricia sabella, became fairly abundant. Where $C$. volutator vanished, juvenile lugworms established dense settlements. In July there were 90 individuals $\mathrm{m}^{-2}$, in November $65 \mathrm{~m}^{-2}$.

* Only the permanently closed cage protected large specimens of the infauna (Table 23). For instance, individuals of Macoma baltica larger than $6 \mathrm{~mm}$ in length

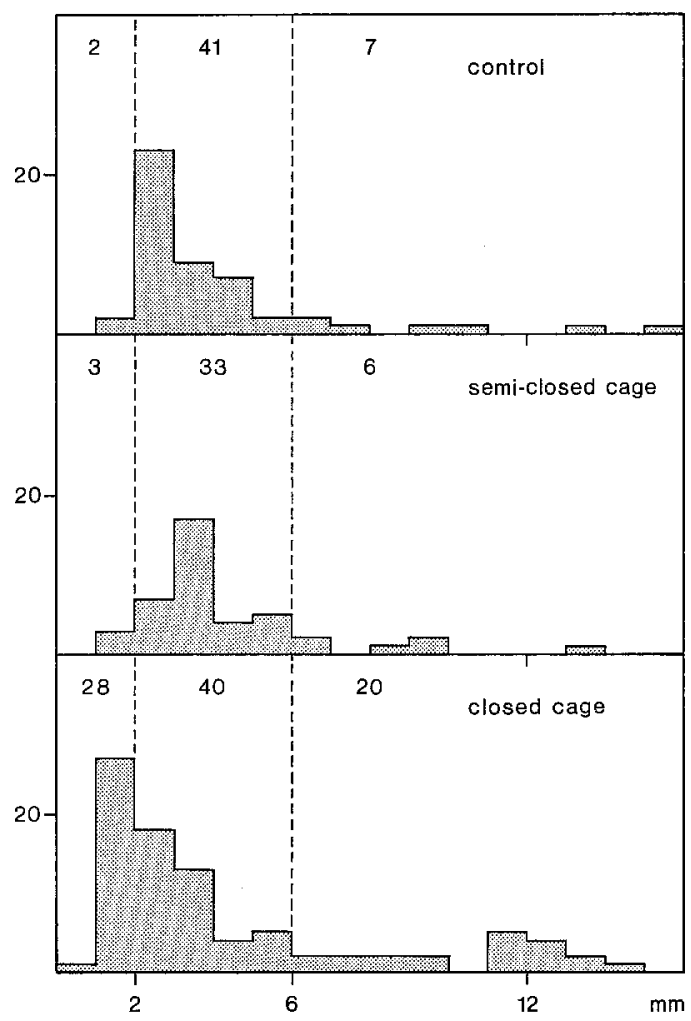

Fig. 17: Size-frequency distributions of Macoma baltica in the Corophium-zone in November 1974; shell length is indicated along the abcissa, individual numbers on the ordinate and in the top of each section refer to $1000 \mathrm{~cm}^{2}$; the increase in abundance of individuals smaller than $2 \mathrm{~mm}$ and larger than $6 \mathrm{~mm}$ within the closed cage is significant $(\mathrm{p} \leq 0.05)$ 
were significantly more abundant within the cage. The same was noticed for spat smaller than $2 \mathrm{~mm}$ in length. Medium sized individuals were evenly distributed among the different plots (Fig. 17). Arenicola marina and Amphiporus lactifloreus were most abundant in the closed cage as well. Small annelids showed no consistent distribution among the three plots.

\section{DISCUSSION}

\section{Composition of infaunal assemblages}

The Coropbium volutator bed represents a dense infaunal tube-building assemblage as defined by Woodin (1976a). The sediment is stabilized and the space below the surface is reduced by vertical tubes of amphipods and polychaetes. Hydobia ulvae is a co-occurring epifaunal snail. However, Woodin's generalizations that tubebuilding forms prevent their own recruitment within the dense assemblage, that they are age-class dominated, and that they are not persistent, do not hold true in this case. Both numerical dominants, C. volutator and $P$. elegans, are able to brood their young and recruitment is continuous except for in the cold season. In this structurally simple habitat, competitive exclusion is likely to determine the composition of the assemblage, at least in intervals between catastrophes, such like severe frost and desiccation.

The fauna in the beds of the small eelgrass Zostera noltii has received little attention so far. The only detailed description is that of Linke (1939). He makes the point, that apart from the stabilizing properties of the rhizomes, the short leaves resuspend fine materials from the sediment surface by swirling around in the tidal currents. This causes the sediment to be more sandy than would be expected in this shallow zone devoid of eelgrass (see also Den Hartog, 1971). The destruction of the eelgrass bed by brent geese can be vary drastic. Similar destruction was observed by Orth (1975) in a bed of $Z$. marina in Chesapeake bay, caused by cownose ray. Thus, although physically stable in general, brent geese, resuspension by swirling leaves, roots and rhizomes reducing space and the position in the upper intertidal zone, cause this habitat to be of intermediate quality for most infaunal members. Competitive exclusion is unlikely to occur, and no trophic group prevails. However, the alternating patches of infaunal species suggest competitive induced habitat segregation. This, and the additional surface for epifaunal species provided by the leaves, favour a high number of species.

The extensive Arenicola marina flat is populated by a deposit feeder assemblage of polychaetes. The dominating lugworm is a tube-dwelling deposit feeder (Jacobsen, 1967), that constantly reworks the sediment. According to Thamdrup (1935), Linke (1939), and Krüger (1971), the position of the tube is fairly constant. This allows for limited colonization of the spaces between funnels and casts by a tube-builder assemblage of spionid polychaetes.

No dense infaunal assemblage is able to persist in the mud flat. The residents do not appear to settle densely enough to allow for competition or amensalism. The drastic decline of species richness and overall abundances occurring in autumn is hardly to be explained in terms of physical factors. About the same phenomenon was ob- 
served by Muus (1967) in the Limfjord. Now and then, the muddy and sandy habitats become occupied by an age-class dominated suspension-feeder assemblage of cockles. Biological interactions are likely to trigger the formation of dense beds, because spat is abundant each year.

\section{Exclusion experiments}

Setting up cages to exclude vagal, epibenthic predators in the Wadden Sea is a fairly crude method. However, by enclosing predators or allowing them to pass through the mesh, I could demonstrate that the major differences between caged and uncaged infauna can be explained in terms of predation. Settlement of juvenile shore crabs (mainly in July) caused a serious problem. Cages with a mesh size of less than $2 \mathrm{~mm}$ trapped these little crabs and, in turn, protected them from predation (except cannibalism). Thus, perfect exclusion of epibenthic predators was only achieved with those cages maintained until the end of June or set up not earlier than the end of July. Another limitation is due to the occurrence of secondary settlement in juvenile bivalves, i.e. in Cerastoderma edule (Baggermann, 1953) and Macoma baltica (Beukema, 1973). Cages with a small mesh size either kept the juveniles inside or prevented their secondary settlement. Also the floating of Hydrobia ulvae was hampered. Corophium volutator migrates in the intertidal zone (Goodhardt, 1941; Watkin, 1941), and may selectively choose cages for settlement. This might have happenend with a 1-mm meshed cage maintained in the mud flat from summer to autumn 1975. In annelids, no such limitations of the caging method are likely to occur.

The exclusion of epibenthic predators in the mud flat and in the sand flat on the one side, and in the eelgrass bed and the Coropbium volutator bed on the other side brought about different results. In the former the cages caused an enormous increase in individual numbers. In the mud flat, $I$ counted up to 16 individuals of macrofauna $\mathrm{cm}^{-2}$, much higher than can be observed anywhere else in the Wadden Sea. In the control area there were only $2 \mathrm{~cm}^{-2}$, or in the eelgrass bed and Corophium bed 5-6 $\mathrm{cm}^{-2}$. In the latter two assemblages, cages did not cause much change. Although in some species a significant increase could be observed, most remained indifferent and some were even less abundant within cages. In the eelgrass bed as well as in the Coropbium volutator bed infaunal predators (some polychaetes, nemerteans) were proportionately more important than in the mud flats and in the sandy areas. These predators responded positively to the cages, and one assumption is that they took over the part of the epibenthic predators. However, experimental proof is not yet available. On the other hand, the position of the eelgrass bed and the Corophium volutator bed in the upper intertidal zone restricts the feeding time of most epibenthic predators. This applies mainly to the Corophium volutator bed, because the eelgrass area remains covered by a layer of water (2-3 cm deep) during normal low tides. With simple experiments in aquaria, I could demonstrate that coarse-grained and rooty sediments provide some spatial resistance to predation by shrimp and young shore crabs (Reise, 1977a). Thus, in the eelgrass bed the infauna finds a certain refuge from epibenthic predation. 
Within the $20-\mathrm{mm}$ meshed cages the situation was the reverse. There were no or only small protective effects in the mud and sand flats, but significant ones in the eelgrass bed and the Corophium volutator zone. This was to be expected, because the heavy predation of small predators on juvenile stages in the lower intertidal zone hardly left anything to grow up into the prey spectra of the larger predators.

\section{The role of predation in the Wadden Sea}

The role of predators considered here is that of unspecialized, temporary members of the Wadden Sea. The impact of more specialized predators will tend to be less severe because of their density adjusted predation. Tests in aquaria (Reise, 1977b) and the exclusion experiments with a sequence of mesh sizes singled out young shore crabs, shrimp, and the common goby to be the most important epibenthic predators in Königshafen. All three are generalists and of temporal occurence on the tidal flats (Plagmann, 1939; Muus, 1967; Ropes, 1969; Healy, 1972; Miller, 1975; Klein Breteler, 1976).

Intense predation starts with the arrival of the predators' O-groups on the flats in early summer (June/July). This coincides with the highest juvenile-abundance of the resident macrofauna. In the structurally simple mud flat, the whole infauna is rapidly diminished and finally severely overexploited, when these predators migrate to deeper waters in early October. Heteromastus filiformis and Peloscolex benedeni are the only one to resist. They keep away from the endangered sediment surface by feeding on bacteria in deeper layers. Only their tails are still in the reach of epibenthic predators. The same applies to the adult Arenicola marina in the sand flat, which sacrifices its tail to flatfish and birds occasionally (Kuipers, 1973; personal observations).

Muus (1967) studied the chronology of predator arrival in shallow waters of the Limfjord and the population dynamics of their potential prey. He essentially found the same phenomenon of „a grazed down bottom fauna“. He pointed out that the O-group predators gradually shift to larger prey sizes with the advancing season. In Königshafen, this may in part explain the abundance of surface-bound juveniles (i.e. C. edule, Spio filicornis) in the sand flat in October. In combination with the refuge offered to the prey by the larger grain size of the sediment (Reise, 1977a) it becomes inefficient for the grown up predators to feed on this resource.

The caging experiments demonstrate that the formation of cockle beds can be triggered when predation pressure is lessened. Once young cockles manage to attain an invulnerable size in respect to the most abundant predators, they are able to live for quite a long time. In Königshafen this happened in summer 1970, and this age-class was still the prevailing one in 1975 , distributed in disjointed patches in sandy and muddy areas below mid-tide level. There seems to be a general pattern of successful settlement in the summer following a severe winter (Thamdrup, 1937; Smidt, 1944; Boyden, 1972), although not exclusively (Wohlenberg, 1937; personal observations). The actual coincidence allowing the juvenile cockles to escape predation is not yet known. In the eelgrass bed, some cockles manage to survive each year. This can be interpreted with the spatial resistance of the rhizome system which offers a refuge from 
predation (Reise, 1977a). This survival of cockles is of special interest, because the caging experiments imply that $C$. edule would be the dominant species below mid-tide level if it were not for predation.

For the lower intertidal zone, I propose that predation is the dominant structuring and organizing force for infaunal assemblages. In the structurally more complex eelgrass habitat and in the Corophium volutator bed positioned in the uppermost intertidal zone predation is mitigated either by spatial resistance or by limited accessibility. However, the role of infaunal predators in these habitats has not yet been experimentally investigated. A summary of the major determinants and characteristics of the four assemblages studied is given in Table 24.

For the rocky intertidal zone, Paine $(1966,1974)$ stressed the importance of predators in causing community structure. Selective predation on dominant competitors is shown to maintain high species diversity by preventing the dominants from monopolizing the available space. Connell (1975) presented a model explaining the frequently observed "mosaics of patches of dominant species", based on the change in intensity of predation as physical conditions vary, and the change in vulnerability of prey as its size varies in relation to that of its predators. Menge \& Sutherland (1976) proposed a quite similar model, and predicted for structurally simple environments either competitive exclusion or overexploitation by predators; and for structurally

Table 24

Determinants of animal assemblages in Königshafen (Sylt).

* occasionally dominated by a dense suspension feeder assemblage of cockles due to escape from predation pressure

\begin{tabular}{|c|c|c|c|}
\hline Habitat & $\begin{array}{l}\text { Intensity of epi- } \\
\text { benthic predation }\end{array}$ & $\begin{array}{l}\text { Major processes deter- } \\
\text { mining the composition } \\
\text { and the dynamics of } \\
\text { the assemblage }\end{array}$ & $\begin{array}{l}\text { Assemblage } \\
\text { characteristics }\end{array}$ \\
\hline $\begin{array}{l}\text { Coropbium } \\
\text { volutator } \\
\text { bed }\end{array}$ & $\begin{array}{l}\text { limited } \\
\text { accessibility for } \\
\text { most predators }\end{array}$ & $\begin{array}{l}\text { competitive exclusion } \\
\text { and occasional physical } \\
\text { disturbances }\end{array}$ & $\begin{array}{l}\text { dense tube builder ass., } \\
\text { momotonous and dis- } \\
\text { crete }\end{array}$ \\
\hline $\begin{array}{l}\text { Zostera noltii } \\
\text { bed }\end{array}$ & $\begin{array}{l}\text { rooty and coarse } \\
\text { grained sediment } \\
\text { provides spatial } \\
\text { resistance } \\
\text { against predation }\end{array}$ & $\begin{array}{l}\text { competitive segregation } \\
\text { in a complex habitat }\end{array}$ & $\begin{array}{l}\text { no trophic group } \\
\text { prevailing, diversified } \\
\text { and discrete ass. }\end{array}$ \\
\hline $\begin{array}{l}\text { Arenicola } \\
\text { marina } \\
\text { flat }\end{array}$ & $\begin{array}{l}\text { coarse grained sand } \\
\text { provides limited } \\
\text { protection against } \\
\text { predators }\end{array}$ & $\begin{array}{l}\text { lugworms cause a } \\
\text { patchy, unstable habitat; } \\
\text { predation }\end{array}$ & $\begin{array}{l}\text { * coexistence of a deposit } \\
\text { feeder and a tube builder } \\
\text { ass., open to further } \\
\text { immigrants }\end{array}$ \\
\hline Mud flat & $\begin{array}{l}\text { unhampered } \\
\text { predation }\end{array}$ & predation & $\begin{array}{l}\text { * overexploited infauna, } \\
\text { except for deep- } \\
\text { dwelling species, } \\
\text { recolonization from } \\
\text { adjacent flats when } \\
\text { predators are absent }\end{array}$ \\
\hline
\end{tabular}


complex environments competition induced habitat specialization as well as reduced predator foraging efficiency.

These models are based on field experiments in the rocky intertidal zone but are not meant to be restricted to this habitat. In principal, they can be applied to Wadden Sea conditions as well. Of special importance are migrations in the Wadden Sea, either with tides or with seasons. A common refuge for prey organismus is the depth of the sediment, and occasionally texture also serves as protection.

At the present state of investigation only a crude model can be proposed for emergent patterns of abundance in the Wadden Sea: Predation is the first order determinant. By keeping abundances low, the prey organisms are prevented from competitive interactions, and potential physiologically determined distributions cannot be realized, they are concealed by predation pressure. This applies to the situation in structurally simple habitats of the lower intertidal zone, and probably to the adjacent subtidal zone as well. When predation becomes less intense, with decreasing time of submergence, abundances can get high enough to allow for competition. Again the physiologically determined niche cannot be realized, this time because of competitive exclusion or suppression. Physical factors, finally, will determine the pattern of abundance only at times following severe disturbances that ravage the whole fauna of the Wadden Sea (i.e. extreme winters). Complex habitat structures, like in the eelgrass bed, prevent overexploitation by predators as well as competitive exclusion. This allows for a diversified assemblage.

In trying to understand the patterns of abundance in the Wadden Sea we have to work down the hierarchy: predation (grazing, parasitism) - competition (amensalism) - physical limits of tolerance. Always the dynamic nature of the determinants has to be taken into account. Previous conditions extend not only into the future by means of long living organisms (i. e. cockles, lugworms) but also by giving birth to assemblages or extensive populations which prove to be resistant against replacement once they are established (see also Fenchel, 1975). This model is meant to reemphasize the complex nature of the determinants of animal assemblages. It shall serve as a guide to further investigations rather than presenting a solution.

Acknowledgements. I wish to thank my fellow students and the staff of the 2. Zoologisches Institut der Universität Göttingen, and of the Litoralstation of the Biologische Anstalt Helgoland, for many stimulating discussions and various technical assistance. I am greatly indepted to Prof. P. Ax for his valuable criticism and his interest in the investigations. Particular thanks are due to Professors J. H. Connell, J. S. Gray and E. Ursin who drew my attention to several bungles and inconsistencies in the study. - The investigations were supported by the Deutsche Forschungsgemeinschaft (Litoralforschung - Abwässer in Küstennähe).

\section{LITERATURE CITED}

Arntz, W. E., 1977. Results and problems of an "unsuccessful" benthos cage predation experiment. In: Biology of benthic organisms. Ed. by B. F. Keegan, P. O. Céidigh \& P. J. S. Boaden. Pergamon Press, New York, 31-44.

Baggerman, B., 1953. Spatfall and transport of Cardium edule L. Archs. néerl. Zool. 10, $315-342$. 
Bartsch, J., 1973. Zur Nahrungsaufnahme von Tetrastemma melanocephalum (Nemertini). Helgoländer wiss. Meeresunters. 25, 326-331.

Beukema, J. J., 1973. Migration and secondary spatfall of Macoma baltica (L.) in the western part of the Wadden Sea. Neth. J. Zool. 23, 356-357.

Blegvad, H., 1928. Quantitative investigations of bottom invertebrates in the Limfjord 1910-1927 with special reference to the plaice-food. Rep. Danish Biol. Stn 34, 33-52.

Boyden, C: R., 1972. Relationship of size to age in the cockles Cerastoderma edule and C. glaucum from the River Crouch Estuary, Essex. J. Conch., Lond. 27, 475-489.

Connell, J. H., 1973. Community interactions on marine rocky intertidal shores. A. Rev. Ecol. Syst. 3, 47-57.

- 1975. Some mechanisms producing structure in natural communities: A model and evidence from field experiments. In: Ecology and evolution of communities. Ed. by M. L. Cody \& J. M. Diamond. Belknap Press, Cambridge, 460-490.

Den Hartog, C., 1971. The dynamic aspect in the ecology of sea-grass communities. Thalassia jugosl. 7, 101-112.

Fenchel, T., 1975. Factors determining the distribution patterns of mud snails (Hydrobiidae). Oecologia 20, 1-17.

Goodhart, C. B., 1941. The ecology of the amphipoda in a small estuary in Hampshire. J. Anim. Ecol. 10, 306-322.

Hancock, D. A. \& Urquhart, A. E., 1965. The determination of natural mortality and its causes in an exploited population of cockles (Cardium edule L.). Fishery Invest., Lond. (Ser. 2) 24 (2), 1-40.

Hartmann-Schröder, B., 1971. Annelida, Polychaeta. Tierwelt Dtl. 58, 1-594.

Healy, M. C., 1972. On the population ecology of the common goby in the Ythan estuary. J. nat. Hist. 6, 133-145.

Jackson, J. B. C., 1972. The ecology of the molluscs of Thalassia communities, Jamaica, West Indies. II. Molluscan population variability along environmental stress gradient. Mar. Biol. 14, 304-337.

Jacobsen, V. H., 1967. The feeding of the lugworm, Arenicola marina (L.). Ophelia 4, 91-109.

Klein Breteler, W. C. M., 1976. Migration of the shore crab, Carcinus maenas, in the Dutch Wadden Sea. Neth. J. Sea Res. 10, 338-353.

Krüger, F., 1971. Bau und Leben des Wattwurmes Arenicola marina. Helgoländer wiss. Meeresunters. 22, 149-200.

Kuipers, B., 1973. On the tidal migration of young plaice (Pleuronectes platessa) in the Wadden Sea. Neth. J. Sea Res. 6, 376-388.

Linke, O., 1939. Die Biota des Jadebusens. Helgoländer wiss. Meeresunters. 1, 201-348.

Lloyd, M., 1967. Mean Crowding. J. Anim. Ecol. 36, 1-30.

Menge, B. A. \& Sutherland, J. P., 1976. Species diversity gradients: Synthesis of the roles of predation, competition, and temporal heterogeneity. Am. Nat. 101, 351-369.

Miller, P. J., 1975. Age-structure and life-span in the common goby, Pomatoschistus microps. J. Zool., Lond. 177, 425-448.

Muus, B. J., 1967. The fauna of Danish estuaries and lagoons. Meddr. Danm. Fisk.-og. Havunders. 5, 1-316.

Orth, R. J., 1975. Destruction of eelgrass, Zostera marina, by the cownose ray, Rbinoptera bonasus, in the Chesapeake bay. Chesapeake Sci. 16, 205-208.

Paine, R. T., 1966. Food web complexity and species diversity. Am. Nat. 100, 65-75.

- 1974. Intertidal community structure. Oecologia 15, 93-120

Rasmussen, E., 1973. Systematics and ecology of the Isefjord marine fauna. Ophelia 11, 1-507.

Rhoads, D. C. \& Young, D. K., 1970. The influence of deposit feeding organisms on sediment stability and community trophic structure. J. mar. Res. 28, 150-178.

Reise, K., 1977a. Predation pressure and community structure of an intertidal soft-bottom fauna. In: Biology of benthic organisms. Ed. by B. F. Keegan, P. O. Céidigh \& P. J. S. Boaden. Pergamon Press, New York, 513-519.

- 1977b. Predator exclusion experiments in an intertidal mud flat. Helgoländer wiss. Meeresunters. 30, 263-271. 
Ropes, J. W., 1968. The feeding habits of the green crab, Carcinus maenas (L.). Fish. Bull. U.S. 67, 183-203.

Sachs, L., 1969. Statistische Auswertungsmethoden. Springer, Berlin, 1-677.

Smith, O. R., 1954. Fencing in flats may save clams from green crabs. Maine Coast Fish. 8 (8), 20.

Thamdrup, H. M., 1935. Beiträge zur Okologie der Wattenfauna. Meddr. Danm. Fisk.-og Havunders. (Fiskeri) 10 (2), 1-125.

Watkin, E. E., 1941. The yearly life cycle of the amphipod Coropbium volutator. J. Anim. Ecol. 10, 77-93.

Wohlenberg, E., 1937. Die Wattenmeer-Lebensgemeinschaften im Königshafen von Sylt. Helgoländer wiss. Meeresunters. 1, 1-92.

Woodin, S. A. 1974. Polychaete abundance patterns in a marine soft-sediment environment. Ecol. Monogr. 44, 171-187.

- 1976a. Adult-larval interactions in dense infaunal assemblages: Patterns of abundance. J. mar. Res. 34, 25-41.

- 1976b. Structural heterogeneity and predation in an infaunal system. Am. Zool. 16, 195.

Young, D. K., Buzas, M. A., and Young, M. W., 1976. Species densities of macrobenthos associated with seagrass: A field experimental study of predation. J. mar. Res. 34, 577-592. 